\title{
The distribution of immunomodulatory cells in the lungs of patients with idiopathic pulmonary fibrosis
}

\author{
Gerard J Nuovo ${ }^{1}$, James S Hagood ${ }^{2}$, Cynthia M Magro ${ }^{3}$, Nena Chin $^{4}$, Rubina Kapil ${ }^{5}$, \\ Luke Davis ${ }^{6}$, Clay B Marsh ${ }^{5}$ and Virginia A Folcik ${ }^{5}$ \\ ${ }^{1}$ Department of Pathology, Ohio State University Medical Center, Columbus, OH, USA; ${ }^{2}$ Pediatric Respiratory \\ Medicine, University of California-San Diego, and Rady Children's Hospital of San Diego, CA, USA; \\ ${ }^{3}$ Department of Pathology and Laboratory Medicine, Weill Cornell Medical College, Cornell University/ \\ New York Presbyterian Hospital, New York, NY, USA ; ${ }^{4}$ Accurate Diagnostic Labs, South Plainfield, NJ, USA; \\ ${ }^{5}$ Department of Internal Medicine, Ohio State University Medical Center, Columbus, OH, USA and \\ ${ }^{6}$ Department of Periodontology, College of Dentistry, Ohio State University Medical Center, Columbus, OH, USA
}

\begin{abstract}
We have characterized the immune system involvement in the disease processes of idiopathic pulmonary fibrosis in novel ways. To do so, we analyzed lung tissue from 21 cases of idiopathic pulmonary fibrosis and 21 (non-fibrotic, non-cancerous) controls for immune cell and inflammation-related markers. The immunohistochemical analysis of the tissue was grouped by patterns of severity in disease pathology. There were

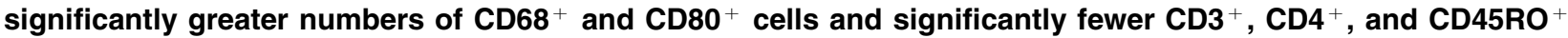
cells in areas of relatively (histologically) normal lung in biopsy samples from idiopathic pulmonary fibrosis patients compared with controls. In zones of active disease, characterized by epithelial cell regeneration and fibrosis, there were significantly more cells expressing CD4, CD8, CD20, CD68, CD80, chemokine receptor 6 (CCR6), S100, IL-17, tumor necrosis factor- $\alpha$, and retinoic acid-related orphan receptors compared with histologically normal lung areas from idiopathic pulmonary fibrosis patients. Inflammation was implicated in these active regions by the cells that expressed retinoid orphan receptor- $\alpha,-\beta$, and $-\gamma$, CCR6, and IL-17. The regenerating epithelial cells predominantly expressed these pro-inflammatory molecules, as evidenced by co-expression analyses with epithelial cytokeratins. Macrophages in pseudo-alveoli and $\mathrm{CD}^{+} \mathbf{T}^{+}$cells in the fibrotic interstitium also expressed IL-17. Co-expression of IL-17 with retinoid orphan receptors and epithelial cytoskeletal proteins, CD68, and CD3 in epithelial cells, macrophages, and T-cells, respectively, confirmed the production of IL-17 by these cell types. There was little staining for forkhead box P3, CD56, or CD34 in any idiopathic pulmonary fibrosis lung regions. The fibrotic regions had fewer immune cells overall. In summary, our study shows participation of innate and adaptive mononuclear cells in active-disease regions of idiopathic pulmonary fibrosis lung, where the regenerating epithelial cells appear to propagate inflammation. The regenerative mechanisms become skewed to ultimately result in lethal, fibrotic restriction of lung function. Modern Pathology (2012) 25, 416-433; doi:10.1038/modpathol.2011.166; published online 28 October 2011
\end{abstract}

Keywords: co-expression analysis; idiopathic pulmonary fibrosis; immunohistochemistry; inflammation; IL-17; retinoic acid-related orphan receptors; usual interstitial pneumonia

Idiopathic pulmonary fibrosis is an incurable lung disease, with a variable clinical course that even-

Correspondence: Dr VA Folcik, PhD, 201 Davis Heart and Lung Research Institute, 473 West 12th Avenue, Columbus, OH 43210, USA.

E-mail: nivar.1@osu.edu

Received 30 June 2011; revised 7 September 2011; accepted 8 September 2011; published online 28 October 2011 tually leads to death. ${ }^{1,2}$ This disease involves lung parenchyma injury that is defined histologically but not epidemiologically. ${ }^{3}$ Idiopathic pulmonary fibrosis is temporally heterogeneous, with regions of lung injury and fibrosis interspersed with normal appearing lung., ${ }^{4,5}$ The prognosis for patients remains grave and there are no effective treatments. There are many controversies regarding the disease, including the role of inflammation, ${ }^{6}$ the causative agent(s) of 
the sporadic injury, ${ }^{7-9}$ and the defective regeneration processes that lead to fibrosis. ${ }^{10}$ We have examined inflammatory pathways at the cellular level in this study, extending the evidence for the role of the highly inflammatory cytokine, IL-17.

Some insights into understanding the course of pulmonary fibrosis have come from animal models of bleomycin-mediated lung injury, revealing participation of inflammatory mediators, ${ }^{11}$ hematopoietic progenitors, ${ }^{12,13}$ and chemokines that attract cells into the sites of injury. ${ }^{14}$ Studies in human idiopathic pulmonary fibrosis indicate a role for circulating progenitor cells, called fibrocytes. ${ }^{15-17}$ However, the source of the fibroblasts that mediate the interstitial deposition of collagen, formation of the fibroblastic foci and the 'fibroblastic reticula', ${ }^{18}$ characteristic of usual interstitial pneumonia, is a controversial issue. ${ }^{19}$ It may be that both progenitor recruitment (fibrocytes) and epithelial-mesenchymal transition ${ }^{20}$ occur in pulmonary fibrosis; definitive evidence remains to be presented.

The purpose of the current study was to analyze in situ the histologically normal, active, and fibrotic regions of idiopathic pulmonary fibrosis lung to characterize the inflammatory cells and mediators present, ${ }^{21-24}$ and to provide a novel description of the cellular cytokine production associated with the disease processes. We examined tissue from control lungs and lungs from cases of idiopathic pulmonary fibrosis for the presence and co-expression of intra- and extracellular markers, pro-inflammatory cytokines and a pleiotropic family of molecules (S100) functioning inside and outside of cells. Our studies reveal disease region-specific expression patterns of inflammatory mediators, particularly in regenerating epithelial cells, which have not been previously described in human idiopathic pulmonary fibrosis.

\section{Materials and methods}

\section{Patient Selection}

Lung tissue specimens from patients with idiopathic pulmonary fibrosis were available from the consult files of GJ Nuovo or the surgical pathology files at the Ohio State University Medical Center. Tissue specimens were selected from patients without diagnosed autoimmune comorbidity. Procurement of the tissue was done according to the guidelines of the approved protocol (Internal Review Board number-2002H0089). All tissues were formalin fixed and paraffin embedded. For controls, we studied an equal number of similarly sized pieces of lung biopsy specimens (which ranged from 1.0 to $2.0 \mathrm{~cm}$ in maximum diameter) with histologically unremarkable lung. The control specimens were obtained from patients with suspected emphysema, but not cancer or pulmonary fibrosis. Recuts of the original tissue stained with hematoxylin and eosin were reviewed by a board-certified anatomic pathologist with expertise in lung pathology (GJN) to verify the original histological diagnosis.

The patient demographics consisted of 21 idiopathic pulmonary fibrosis patients, including 8 men with a mean age of $61 \pm 10$ ( \pm s.d.) years, 2 women with a mean age of 62 years, and 11 patients of unknown age and gender (de-identified idiopathic pulmonary fibrosis lung tissue provided by Dr Moises Selman). The 21 controls included 13 males with a mean age of $68 \pm 7$ years, 7 females with a mean age of $66 \pm 11$ years, and one person of de-identified age and gender.

\section{Histological Variables}

The histological features of the lungs from patients with idiopathic pulmonary fibrosis were divided into three categories based upon the pathological severity, all with the diagnosis of usual interstitial pneumonia. These were normal histological findings (idiopathic pulmonary fibrosis-normal lung area), defined as lung tissue that at $\times 200$ could not be differentiated from the lung tissue of the controls; lung with alveolar damage, defined as loose myxomatous-like interstitial fibrosis associated with the presence of either persistent alveolar-lining epithelia or regenerating respiratory epithelial cells (idiopathic pulmonary fibrosisepithelial dominant), frequently accompanied by inter-alveolar fibroblast foci; and a fibrosis-only stage (idiopathic pulmonary fibrosis-stromal dominant), defined as the presence of variable numbers of small blood vessels and dense fibrous tissue. Regenerating epithelial cells were lacking at this last stage, although entrapped pseudoalveolar spaces were common. In the latter two stages, scattered stromal inflammatory cells and either subpleural or perivascular large lymphocytic infiltrates (typically from 100 to $>1000$ cells) were commonly seen. It should be noted that these categories represent a continuing spectrum of disease severity, and all of the signature histological regions of usual interstitial pneumonia can be found in lung tissue from an idiopathic pulmonary fibrosis patient, defining the concept of temporal heterogeneity.

\section{Immunohistochemistry}

The immunohistochemistry testing was done as previously described. ${ }^{25}$ Formalin-fixed, paraffinembedded tonsil tissues with chronic tonsillitis were used to optimize each antibody. In brief, the optimization protocol included testing serial sections with no pretreatment, protease 1 (Ventana Medical Systems) digestion for $4 \mathrm{~min}$, or cell conditioning one (CC1) solution (antigen retrieval) at $95{ }^{\circ} \mathrm{C}$ for $30 \mathrm{~min}$ or, when necessary, $60 \mathrm{~min}$ (CC1 30 and CC1 60) at two different primary antibody concentrations. ${ }^{26}$ Sections were then scored for 
signal and background to determine the optimal conditions. The use of tonsils as the positive control tissue provided another layer of specificity to the analyses, as the expected histological distribution of the immunophenotypic markers probed for in this study has been, in most cases, well characterized in tonsils.

\section{Primary Antibodies and Detection System}

The primary antibodies used in this study with their optimal condition are listed in Table 1. Antibodies that were used without dilution are described as ready to use. As previously reported,$^{25}$ the Ultraview Universal Fast Red (Fast Red) and diaminobenzidine

Table 1 Antibodies to immunophenotypic markers used

\begin{tabular}{|c|c|c|c|c|}
\hline $\begin{array}{l}\text { Antibody name } \\
\text { (anti-) }\end{array}$ & Description & Source & Dilution & $\begin{array}{l}\text { Tissue } \\
\text { pretreatment }\end{array}$ \\
\hline CCR6 & $\begin{array}{l}\text { Chemokine receptor } 6 \text {; ligands are CCL20 (MIP- } 3 \alpha \text { or LARC) and } \\
\text { human } \beta \text {-defensin- } 2 .{ }^{50} \text { Expressed on memory T cells, } \\
\text { B cells and dendritic cells; }{ }^{32} \text { highly expressed on Th- } 17 \mathrm{~s}^{33}\end{array}$ & Abcam & $1: 200$ & CC1 30 \\
\hline CD1a & $\begin{array}{l}\text { Leu6, OKT6; found on T cells, normal Langerhans cells, immature } \\
\text { dendritic cells, }{ }^{70} \text { and cortical thymocytes. }{ }^{71} \text { It functions in dendritic } \\
\text { cell presentation of glycolipid antigens }{ }^{72} \text { and dendritic cell anti-tumor } \\
\text { response. }{ }^{73} \text { In disease states, it labels histiocytes }{ }^{74} \text { and leukemic } \\
\text { thymocytes }^{71}\end{array}$ & Abcam & $1: 10$ & CC1 30 \\
\hline CD3 & $\begin{array}{l}\text { OKT3; an integral membrane protein complex that is part of the } \\
\text { T-cell antigen receptor }{ }^{75}\end{array}$ & Ventana & Ready to use & CC1 30 \\
\hline CD4 & OKT4, Ly1, Leu3; marker of T-helper lymphocytes ${ }^{76}$ & Ventana & Ready to use & CC1 30 \\
\hline CD8 & $\begin{array}{l}\text { OKT8, Ly2/Ly3, Leu2; marker of cytotoxic T lymphocytes, }{ }^{77} \\
\text { a coreceptor with cCD3 for antigens displayed by MHC Class } \mathrm{I}^{+} \\
\text {antigen-presenting cells }{ }^{78}\end{array}$ & Ventana & Ready to use & CC1 30 \\
\hline CD20 & $\begin{array}{l}\text { L26; a common B-cell surface marker for all but the initial } \\
\text { and final stages of B-cell differentiation, }{ }^{79} \text { used as a target } \\
\text { for eliminating B cells with rituximab in lymphomas and autoimmune } \\
\text { diseases }\end{array}$ & Ventana & Ready to use & CC1 30 \\
\hline CD34 & $\begin{array}{l}\text { Common surface marker for adult hematopoietic progenitor cells, }{ }^{80} \\
\text { murine hematopoietic cells, }{ }^{81} \text { fibrocytes, }{ }^{82} \text { and endothelial cells }{ }^{83,84}\end{array}$ & Ventana & Ready to use & CC1 30 \\
\hline CD45 & $\begin{array}{l}\text { Leukocyte cell surface glycoprotein },^{85} \text { mononuclear cells, } \\
\text { and fibrocytes. }{ }^{66}\end{array}$ & Ventana & Ready to use & CC1 30 \\
\hline CD45RO & UCHL1; memory T cells, fibrocytes, monocytes, and macrophages ${ }^{66}$ & Ventana & Ready to use & None \\
\hline CD56 & N-CAM, NKH-1, Leu-19; marker for natural killer cells ${ }^{86}$ & Ventana & Ready to use & CC1 30 \\
\hline CD68 & $\begin{array}{l}\text { KP1, macrosialin; glycosylated membrane protein expressed by tissue } \\
\text { macrophages, Langerhans cells, }{ }^{87} \text { monocytes, and fibrocytes }{ }^{66}\end{array}$ & Ventana & Ready to use & CC1 30 \\
\hline CD80 & $\begin{array}{l}\text { B7-1, BB1; a co-stimulatory molecule found on antigen-presenting } \\
\text { cells, including dendritic cells, }{ }^{88} \text { activated } \\
\text { B-cells, }{ }^{89} \text { macrophages, and epithelial cells }{ }^{90}\end{array}$ & Abcam & $1: 100$ & None \\
\hline $\begin{array}{l}\text { Cytokeratin } \\
\text { AE1/AE3 }\end{array}$ & $\begin{array}{l}\text { Labels the most of the cytokeratins of the cytoskeleton }{ }^{91} \\
\text { in normal epithelia and epithelial carcinomas, }{ }^{92} \text { some abnormal } \\
\text { myofibroblasts, and normal smooth muscle cells }{ }^{93}\end{array}$ & DAKO & $1: 150$ & Protease \\
\hline Foxp3 & $\begin{array}{l}\text { Forkhead-winged helix transcription factor that defines } \\
\text { the regulatory } \mathrm{T} \text { cells }{ }^{24}\end{array}$ & Abcam & $1: 100$ & CC1 30 \\
\hline IL-17 & $\begin{array}{l}\text { One member of a highly inflammatory cytokine family } \\
\text { (IL-17a-f) with chemotactic properties that binds with receptors on } \\
\text { most cell types }\end{array}$ & Abcam & $1: 200$ & CC1 30 \\
\hline ROR- $\alpha$ & $\begin{array}{l}\text { Retinoic acid-related orphan receptor alpha, (NR1F1, a thyroid } \\
\text { hormone-like receptor), a transcription factor expressed } \\
\text { in the epithelium of many tissues. }{ }^{51} \text { Required for lymphocyte } \\
{\text { development. }{ }^{37,56} \text { A receptor for cholesterol and its derivatives }}^{94}\end{array}$ & Abcam & $1: 100$ & CC1 30 \\
\hline $\mathrm{ROR}-\beta$ & $\begin{array}{l}\text { Retinoic acid-related orphan receptor- } \beta \text { (NR1F2), present } \\
\text { in the brain and retina }{ }^{52,95}\end{array}$ & Abcam & $1: 300$ & CC1 30 \\
\hline ROR- $\gamma$ & $\begin{array}{l}\text { Retinoic acid-related orphan receptor gamma (NR1F3), required for } \\
\text { the lymphoid tissue development, }{ }^{36} \text { found in thymocytes, Th- } 17 \\
\text { lymphocytes, }{ }^{95} \text { innate lymphoid cells, }{ }^{96} \text { and skeletal muscle cells }{ }^{97}\end{array}$ & Abcam & $1: 200$ & CC1 30 \\
\hline S100 & A family of intracellular and secreted calcium-binding proteins ${ }^{30,31}$ & Ventana & Ready to use & Protease \\
\hline $\mathrm{TNF}-\alpha$ & Part of the TNF superfamily ${ }^{98}$ & Abcam & $1: 100$ & Protease \\
\hline
\end{tabular}

NR1F1, nuclear receptor 1; TNF, tumor necrosis factor. 
detection systems from Ventana Medical Systems were used for bound antibody detection following the manufacturer's recommendations.

\section{Co-Expression Analyses}

Co-expression analyses were performed using the Nuance system (Cambridge Research Institute) according to the manufacturer's specifications and as previously published. ${ }^{25}$ In brief, the Nuance system converts co-expression-based colorimetric analysis (diaminobenzidine brown for one protein and Fast Red for the other protein, with blue hematoxylin counterstain for nuclei) into spectral signatures that can be digitally separated and then 'mixed' to determine whether a given cell is producing two distinct proteins. These images are depicted as pseudo-fluorescent for ease of visualization. The Nuance system will score a cell positive for co-expression even if the proteins are in different cell compartments, as long as the signals for each protein are within a $150-\mathrm{nm}$ plane in three-dimensional space. ${ }^{25,27}$

\section{Statistical Analyses}

For each immunohistochemical analysis for a given antigen and disease pattern, a minimum of three $\times 200$, non-overlapping fields were counted from one slide and averaged, and at least two slides from three patients with idiopathic pulmonary fibrosis as well as the same from two negative controls were analyzed. Statistical comparisons were made using GraphPad Prism 5.0 software and a two-sided Student's $t$-test with the Bonferroni correction. The Bonferroni correction was applied to the $P$-values, which were adjusted by a factor equivalent to the number of comparisons made, usually four.

\section{Results}

Description of Lung Tissue from Idiopathic Pulmonary Fibrosis Biopsy Specimens and Control Lung Tissues

We correlated the histological features of 21 samples and 21 controls with the immunohistochemical detection of the following proteins: CD1a, CD3, CD4, CD8, CD20, CD34, CD45, CD45RO, CD56, CD68, CD80, retinoic acid-related orphan receptor (ROR)- $\alpha$, ROR- $\beta$, ROR- $\gamma$, forkhead box p3 (Foxp3), chemokine receptor 6 (CCR6), S100, IL-17, and tumor necrosis factor (TNF)- $\alpha$. All of the antibodies used are described in Table 1. In three of the idiopathic pulmonary fibrosis cases, there was sufficient tissue to test each of these antigens on serial $4 \mu$ sections. For the other 18 idiopathic pulmonary fibrosis cases, where the amount of tissue was limited, at least 3 idiopathic pulmonary fibrosis cases and 2 control lung cases were used to test each antibody.
The control tissues showed normal lung tissue in the majority of microscopic fields. In some samples, scattered areas of alveolar wall breakdown consistent with early emphysema were seen. However, there were no patterns of increased interstitial fibrosis seen in controls. The idiopathic pulmonary fibrosis lungs globally showed a heterogeneous pattern of fibrosis. In all cases, there was extensive alteration of the parenchymal architecture with only small zones of relatively uninvolved parenchyma. Foci of active injury were characterized by conspicuous type II pneumocyte hyperplasia, fibroblastic foci, and expansion of discernible septa by lymphocytes, plasma cells, and histiocytes. Neutrophilic infiltrates were rare. It was common to observe sheets of macrophages with variable pigment deposition within the alveolar spaces, although this was not unusual in the control lungs as well. Variable vascular injury and hemorrhage were noted in more advanced areas of fibrosis. There was an obliterative pattern of fibrosis, with large, irregular pseudoalveolar spaces characteristically exhibiting interlobar and subpleural accentuation.

\section{Idiopathic Pulmonary Fibrosis Normal Lung Tissue Versus Control Lung Tissue}

Figure 1 shows the quantities of mononuclear cells and macrophages detected by immunohistochemistry using immunophenotypic markers to identify the cell types in control lung and the idiopathic pulmonary fibrosis lung grouped into three distinct stages. Given that the normal appearing areas of idiopathic pulmonary fibrosis lungs may have the earliest markers of disease, it is important to look for differences in these areas that may reveal the etiology of idiopathic pulmonary fibrosis. A comparison of histologically normal lung from the idiopathic pulmonary fibrosis cases and the control lung tissues found that fewer than one cell $/ \times 200$ field stained with the following markers: CD20, CD34, CCR6, and Foxp3 (Figures 1, 2, and data not shown). Alternatively, CD3+, CD4+, CD8+, CD45+, and CD45RO+ cells were commonly detected in the histologically normal idiopathic pulmonary fibrosis lung tissue, corresponding at times to small foci of interstitial lymphocytic infiltration. Figures 1 and 2 show there were significantly more cells in the histologically normal lung tissue in idiopathic pulmonary fibrosis lung biopsy specimens than in lung tissue from control cases that were stained for CD68 $(P=0.0304)$ and CD80 $(P=0.0116)$. Only $\mathrm{CD}^{+}{ }^{+}$cells in the interstitium were counted; the alveolar macrophages were not counted. Although there were quantitatively more TNF- $\alpha^{+}$cells in normal lung tissue in idiopathic pulmonary fibrosis biopsy specimens than in control lung tissue, the difference was not significant. Macrophages and dendritic cells appeared to be attracted to the normal-appearing interstitial areas in idiopathic 


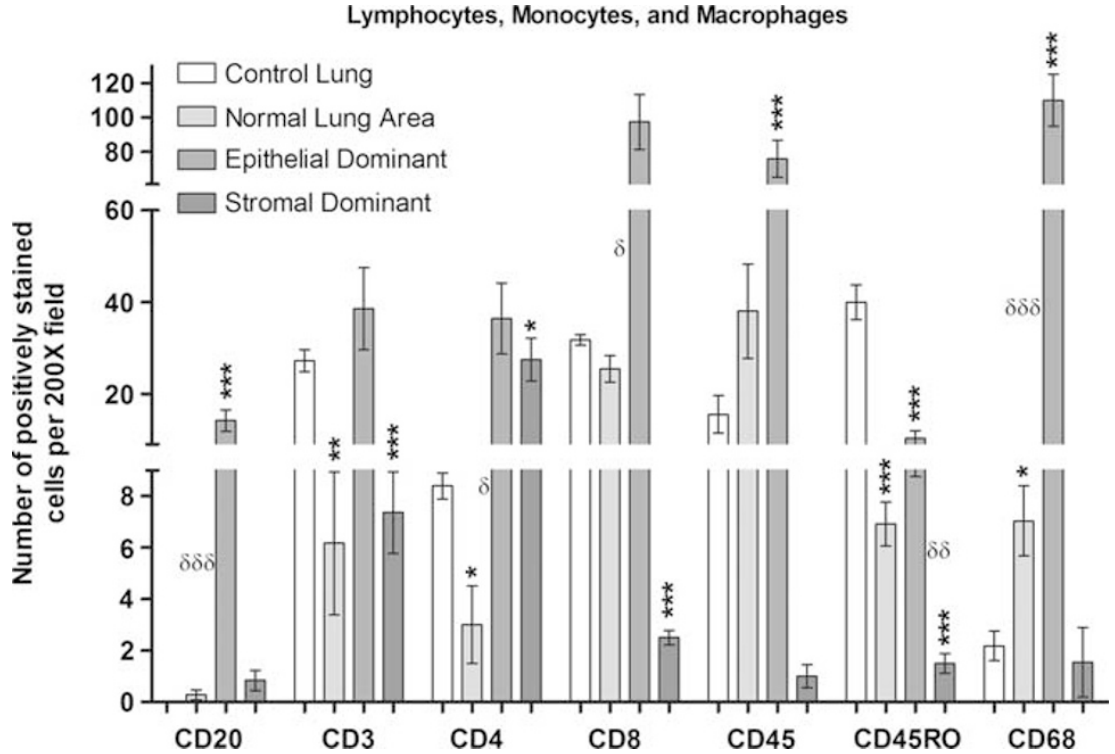

Figure 1 Lymphocytes, monocytes, and macrophages. The mean \pm s.e.m. of the numbers of cells stained positive for the labeled surface antigens on slides with lung tissue from the indicated idiopathic pulmonary fibrosis signature histological regions and control lung tissue. Asterisks indicate the $P$-values for comparison of the idiopathic pulmonary fibrosis tissues with the control lung tissue $\left({ }^{*} P<0.05\right.$; ${ }^{*} P<0.005$; and $\left.{ }^{* * *} P<0.0005\right)$. Deltas indicate the $P$-values for comparison of the differences involving the data bars that they appear between $\left({ }^{\delta} P<0.05 ;{ }^{\delta \delta} P<0.005\right.$; and $\left.{ }^{\delta \delta \delta} P<0.0005\right)$.

\section{Cell Markers and Cytokines}

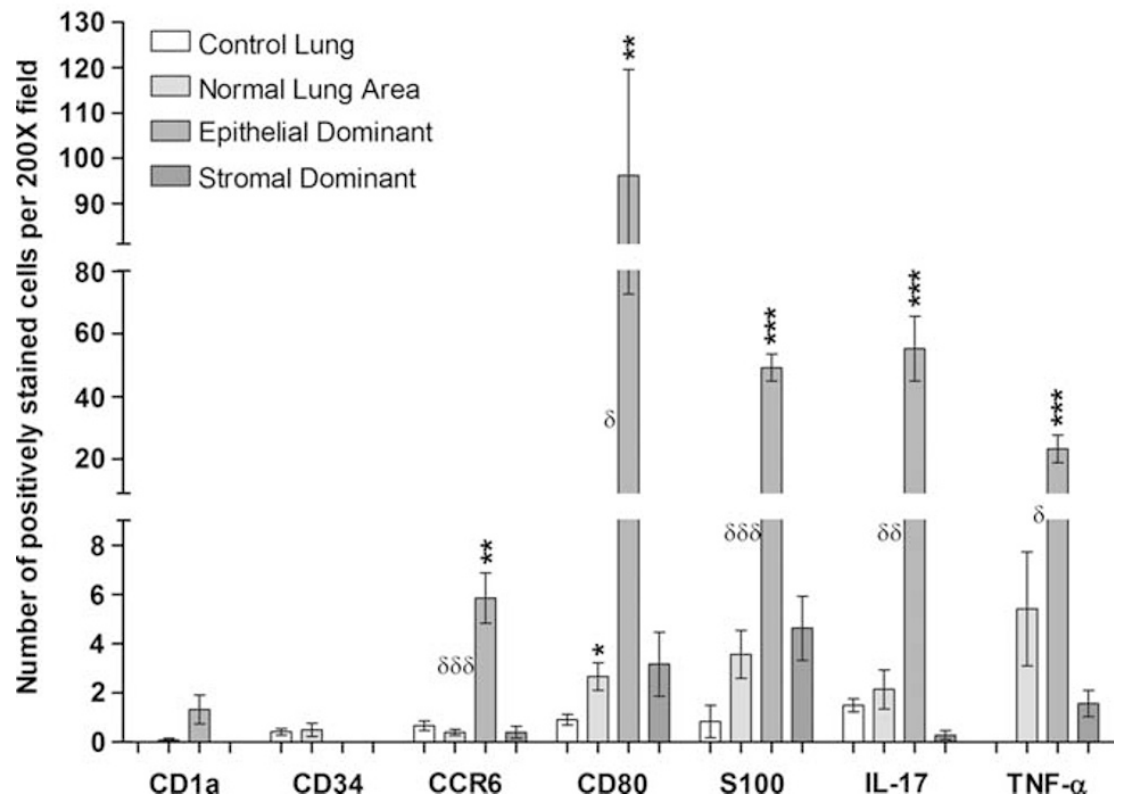

Figure 2 Cell markers and cytokines. The mean \pm s.e.m. of the numbers of cells stained positive for the indicated antigens, chemokine receptors, or cytokines on slides with lung tissue from the indicated idiopathic pulmonary fibrosis signature histological regions or control lung tissue. Asterisks indicate the $P$-values for comparison of the idiopathic pulmonary fibrosis tissues with the control lung tissue $\left({ }^{*} P<0.05 ;{ }^{*} P<0.005\right.$; and $\left.{ }^{* * *} P<0.0005\right)$. Deltas indicate the $P$-values for comparison of the differences involving the data bars that they appear between $\left({ }^{\delta} P<0.05 ;{ }^{\delta \delta} P<0.005\right.$; and $\left.{ }^{\delta \delta \delta} P<0.0005\right)$

pulmonary fibrosis; this was the first detected immune activity.

The comparison of histologically normal lung in idiopathic pulmonary fibrosis lung biopsy material with control lung tissue (Figure 1) revealed signi- ficantly fewer cells positive for CD3 $(P=0.0028)$, CD4 $(P=0.0488)$, and CD45RO $(P<0.0005)$. The numbers of $\mathrm{CD} 8{ }^{+}$cells from the normal areas of the idiopathic pulmonary fibrosis lungs and controls were similar. Although there were slightly more 
Control Lung

IPF Normal
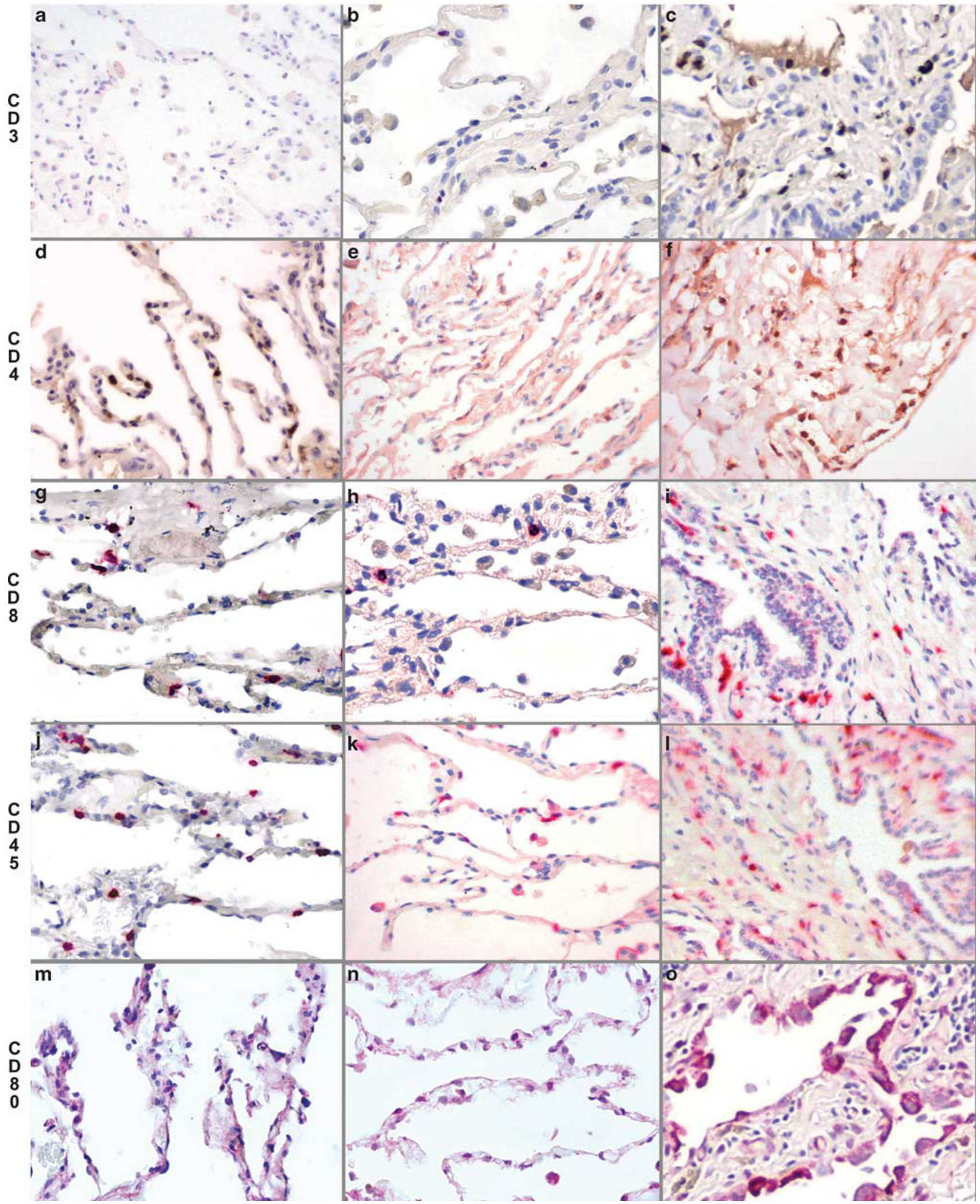

Figure 3 Control lung, idiopathic pulmonary fibrosis-normal lung, and idiopathic pulmonary fibrosis-epithelial-dominant lung. $(\mathbf{a}, \mathbf{d}, \mathbf{g}, \mathbf{j}, \mathbf{m})$ Lung tissue from the controls probed for the indicated cellular markers; (b, e, h, $\mathbf{k}, \mathbf{n})$ the staining of histologically normal lung from idiopathic pulmonary fibrosis patients; and $(\mathbf{c}, \mathbf{f}, \mathbf{i}, \mathbf{l}, \mathbf{o})$ the staining of the epithelial-dominant or -active phase of idiopathic pulmonary fibrosis. All photomicrographs show the tissue with a magnification of $\times 200$. (a-f) The tissues were stained with diaminobenzidine, $(\mathbf{g}-\mathbf{0})$ the tissues were stained with Fast Red. The counterstain in each case was hematoxylin. 
CD45 cells in the normal lung areas from patients with idiopathic pulmonary fibrosis compared with controls, the difference was not statistically significant. Fewer than expected T-helper cells $\left(\mathrm{CD} 4^{+}\right)$, including memory cells $\left(\mathrm{CD} 45 \mathrm{RO}^{+}\right)$, were present in the normal areas of the idiopathic pulmonary fibrosis lung biopsy specimens. Figure 3 shows representative photomicrographs for the detection of various mononuclear cells in the control lungs (Figure 3; photos 3a, 3d, 3g, 3j, and 3m), for the normal areas of idiopathic pulmonary fibrosis lungs (Figure 3; photos 3b, 3e, 3h, 3k, and 3n), and for the epithelial-dominant areas of idiopathic pulmonary fibrosis (Figure 3; photos 3c, 3f, 3i, 3l, and 3o).

\section{Inflammatory infiltrates}

Figure 4 shows examples of cell markers found in inflammatory infiltrates. The inflammatory cell infiltrates were most conspicuous in the areas corresponding to recent parenchymal injury.
The density of each infiltrate was variable and ranged from 100 to over 1000 cells, but it was never of the magnitude found in lymphocytic interstitial pneumonitis. Inflammatory infiltrates usually showed either subpleural or perivascular localization. The $\mathrm{CD}^{+}{ }^{+} \mathrm{T}$ cells were located around the edges and CD20 ${ }^{+}$B-cells were in the center (Figure $4 \mathrm{a}$ and c), as previously described. ${ }^{28}$ Immunohistochemistry for the leukocyte common antigen, CD45, strongly stained the infiltrate cells (Figure 4b). Fewer cells were positive for CD45RO, a marker of memory T-helper cells and myeloid hematopoietic progenitors. ${ }^{29}$ Interestingly, Foxp $3^{+}$cells were visible with nuclear staining in the inflammatory infiltrates (Figure 4e), but not in the areas of active fibrosis (data not shown). IL-17 ${ }^{+}$cells were present in the inflammatory infiltrates (Figure 4g). ROR- $\beta^{+}$ cells were not apparent among the lymphocytes, but some positive epithelial cells can be seen in the vicinity of the infiltrate (Figure 4f). Immunohistochemistry analysis for CCR6 $^{+}$cells follows a similar
CD3

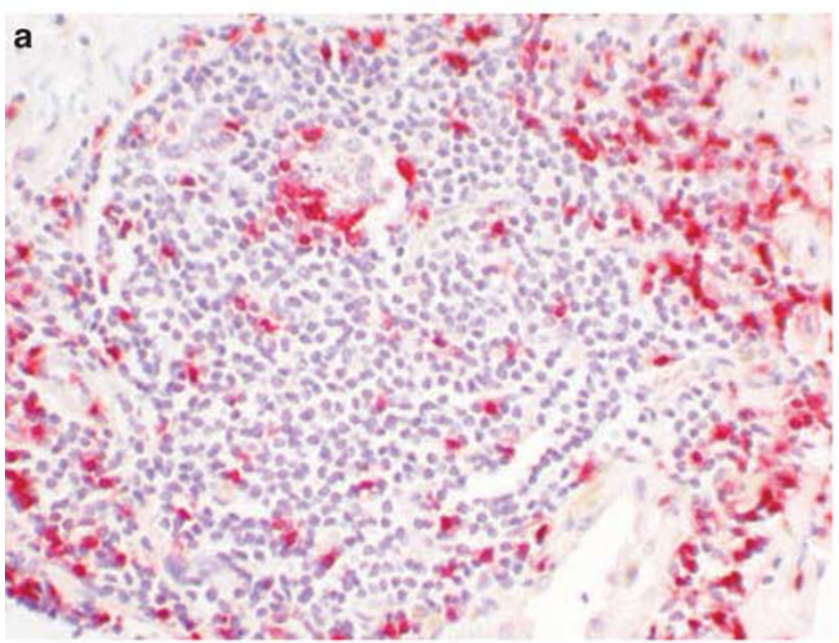

CD20

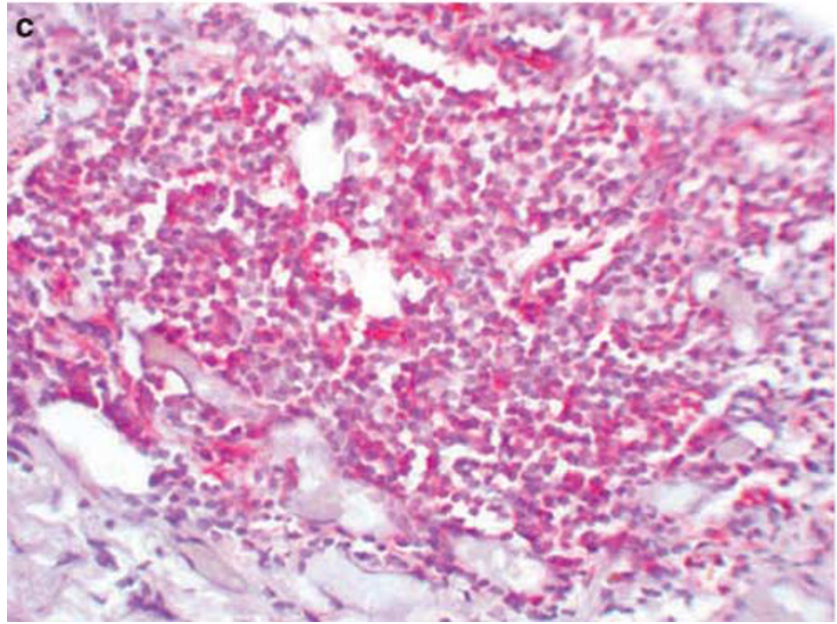

CD45

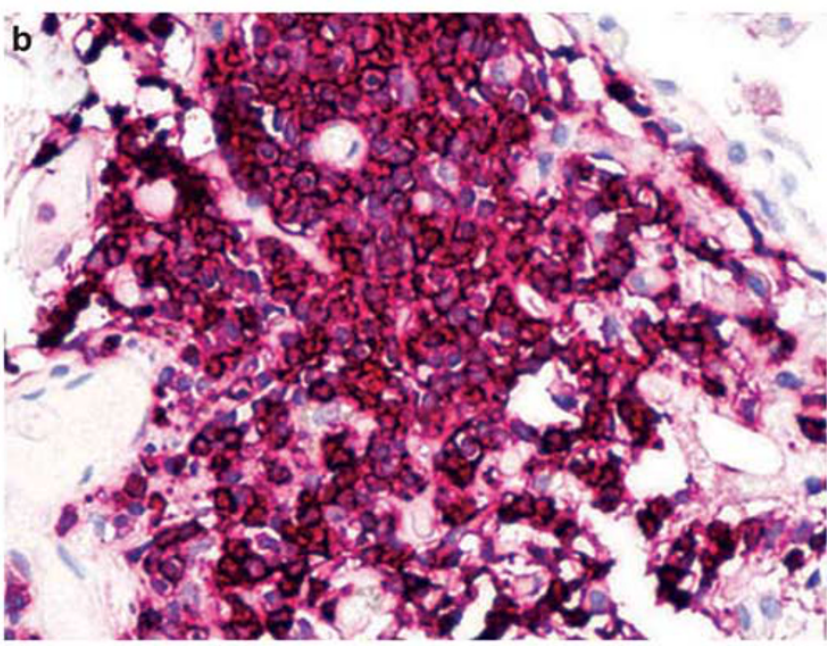

CD45RO

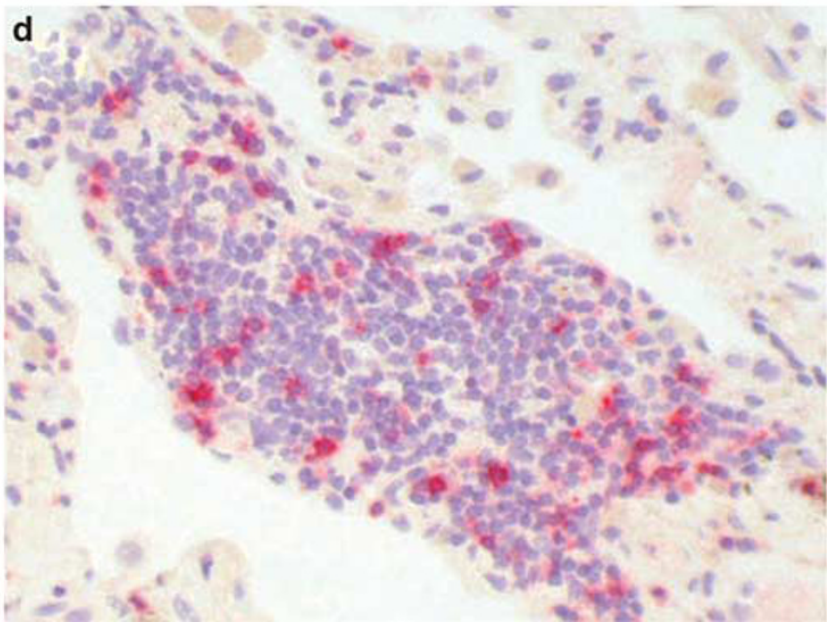

Figure 4 Idiopathic pulmonary fibrosis inflammatory infiltrates. All photomicrographs show the tissue stained with Fast Red and hematoxylin counterstain. (a-f) The photos have a magnification of $\times 200$. (g, h) The photos have a magnification of $\times 400$. 

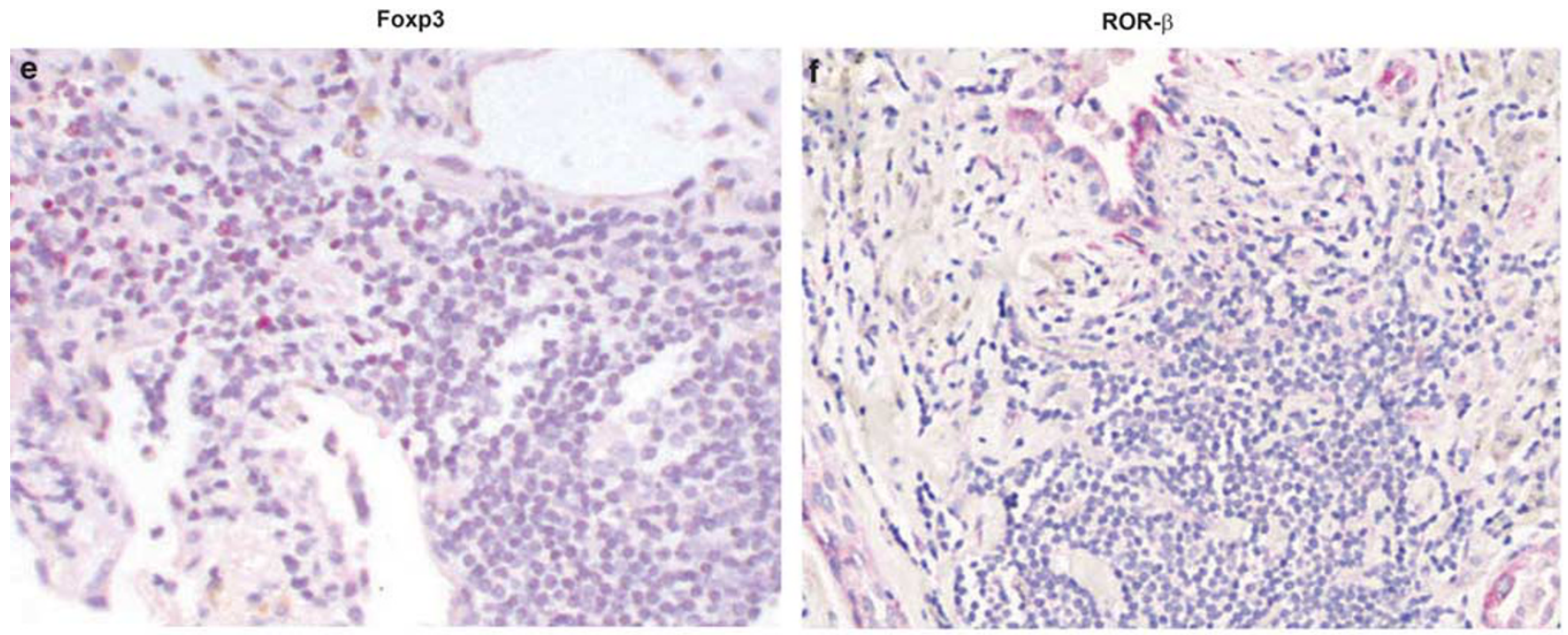

IL-17

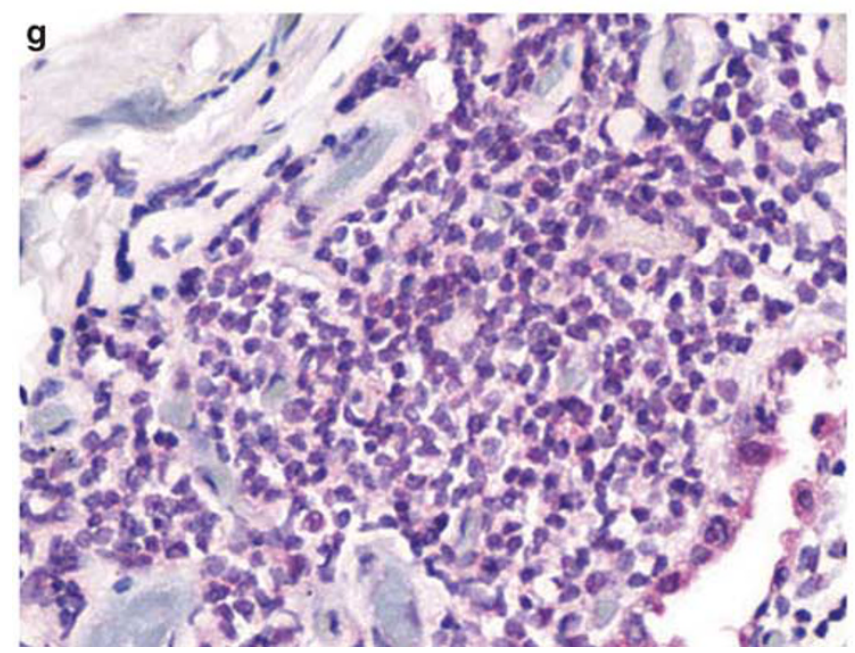

CCR6

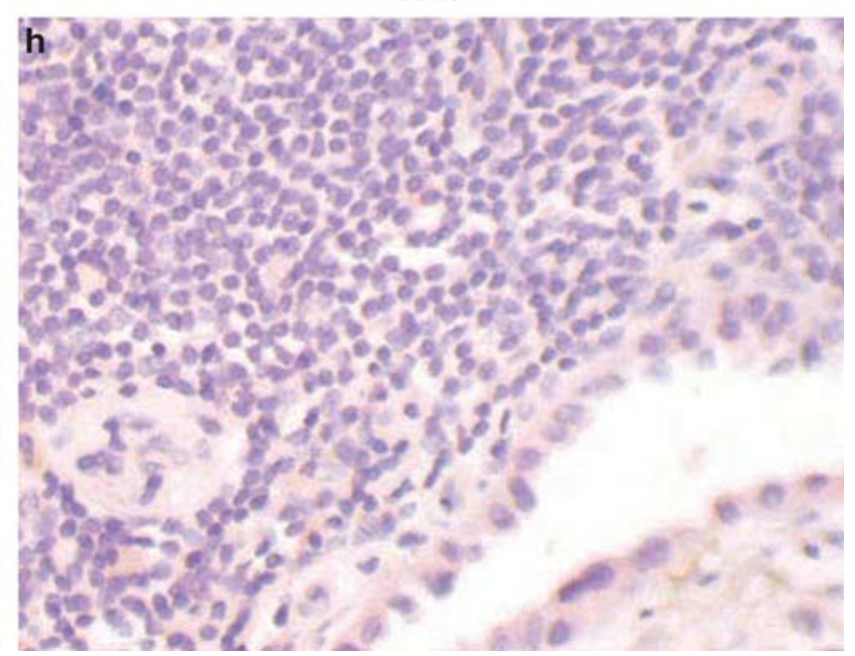

Figure 4 Continued.

pattern, with scattered staining of nearby epithelial cells, but no positive lymphocytes (Figure 4h).

\section{Idiopathic Pulmonary Fibrosis: Epithelial-Dominant Lung Tissue Characterization}

Cells in sites of the active disease (idiopathic pulmonary fibrosis-epithelial dominant) were analyzed. The mean numbers of mononuclear cells and macrophages $/ \times 200$ field in the epithelial-dominant areas of idiopathic pulmonary fibrosis are presented in Figure 1. The CD45RO ${ }^{+}$population was smaller than in control lung tissue $(P<0.0005)$. CD45RO ${ }^{+}$ cells were present in the inflammatory cell infiltrates in idiopathic pulmonary fibrosis (Figure 4d), but were much less common in the areas of active or chronic fibrosis. Significantly, more cells expressing CD20, CD45, and CD68 were detected in the epithelial-dominant stage of idiopathic pulmonary fibrosis compared with controls (Figure 1, $P=0.0004$,
$P<0.0004$, and $P<0.0004$, respectively). $\mathrm{CD}^{+}$, $\mathrm{CD}^{+}, \mathrm{CD}^{+}, \mathrm{CD}^{+} 5^{+}$, and $\mathrm{CD} 80^{+}$cells were abundant in the epithelial-dominant regions of idiopathic pulmonary fibrosis lung (Figure 3, photos 3c, 3f, 3i, 3l, and 3o). Though many of the $\mathrm{CD} 3^{+}, \mathrm{CD} 4^{+}$, and $\mathrm{CD}^{+}$cells had the typical mononuclear cytology, others had spindle-like features. The $\mathrm{CD}^{+}{ }^{+}$cells were actively regenerating epithelia (Figure 3o). The number of $\mathrm{CD}^{+}$cells was significantly greater in the epithelial-dominant stage of idiopathic pulmonary fibrosis compared with the normal idiopathic pulmonary fibrosis lung $(P=0.0076)$, but not when compared with the control lung tissue (Figure 1). Cells expressing CD45 were typically mononuclear cells (Figure $3 \mathrm{k}$ ), but some were larger interstitial cells with myofibroblast features (Figure 3l) resembling cells reported to be derived from circulating fibrocytes. ${ }^{17}$ Cells expressing the regulatory T-cell marker Foxp3 or the NK marker CD56 were neither detected in the epithelial-dominant phase of idiopathic pulmonary fibrosis (similar to the control) nor 
in the histologically normal idiopathic pulmonary fibrosis lung areas (data not shown).

Interestingly, the IL- $17^{+}$cells stained regenerating epithelial cells and alveolar macrophages, and some interstitial cells were also positive (Figure 5e and f). Cytological examination showed that the primary cells expressing TNF- $\alpha$ had the features of macrophages; though occasional, TNF- $\alpha^{+}$regenerating epithelial cells were seen (Figure 5a and b).

The regenerating epithelial cells in the idiopathic pulmonary fibrosis present in the epithelial-dominant areas of lung sections expressed other markers such as the antigen-presenting marker CD80 (Figure 5c and d). CD80 ${ }^{+}$cells were sometimes seen in the stroma but were primarily regenerating epithelial cells. S100 is a protein typically found in and released by phagocytes. ${ }^{30,31}$ $\mathrm{S} 100^{+}$cells were abundant in the active-disease stage (Figure 2), and are present in the stroma
(Figure 5g and $\mathrm{h}$ ). The numbers of cells expressing S100 and CD80 were 50- to 100-fold higher (respectively) in epithelial-dominant lung tissue of idiopathic pulmonary fibrosis than in control lung tissue (Figure 2).

CCR6 is expressed on memory T cells, Th-17s, and T-regs. ${ }^{32,33}$ There were significantly more cells expressing CCR6 in the active idiopathic pulmonary fibrosis biopsy tissue than in controls $(P=0.0006$; Figure 2). Given that regenerating epithelial cells appeared to be the major cell type expressing a variety of inflammatory antigens, we performed co-expression analyses to further address this point. Co-expression studies were done with serial sections to compare the same groups of cells in adjacent sections that are $4 \mu$ thick (in comparison, the regenerating epithelial cells are typically around $15-20 \mu$ in size). The tissue was probed with cytokeratin AE1/3 antibodies for epithelial antigens

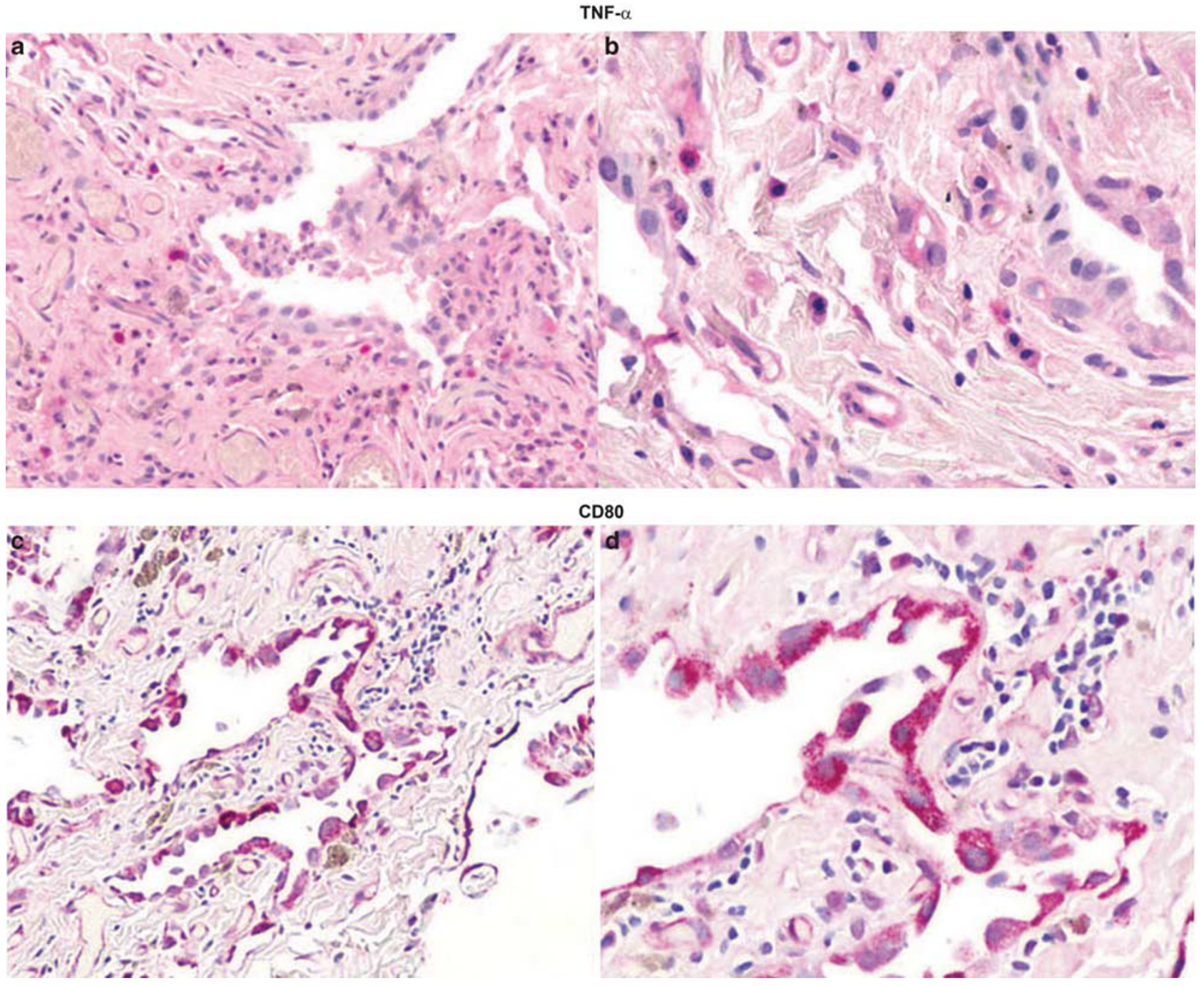

Figure 5 Idiopathic pulmonary fibrosis-epithelial-dominant areas. (a-f) Idiopathic pulmonary fibrosis lung tissue stained with Fast Red and hematoxylin counterstain. (g, h) Idiopathic pulmonary fibrosis lung tissue stained with diaminobenzidine and hematoxylin counterstain. (a, $\mathbf{c}, \mathbf{e}, \mathbf{g})$ The photos have a magnification of $\times 100$, whereas the others have a magnification of $\times 400$. 
IL-17
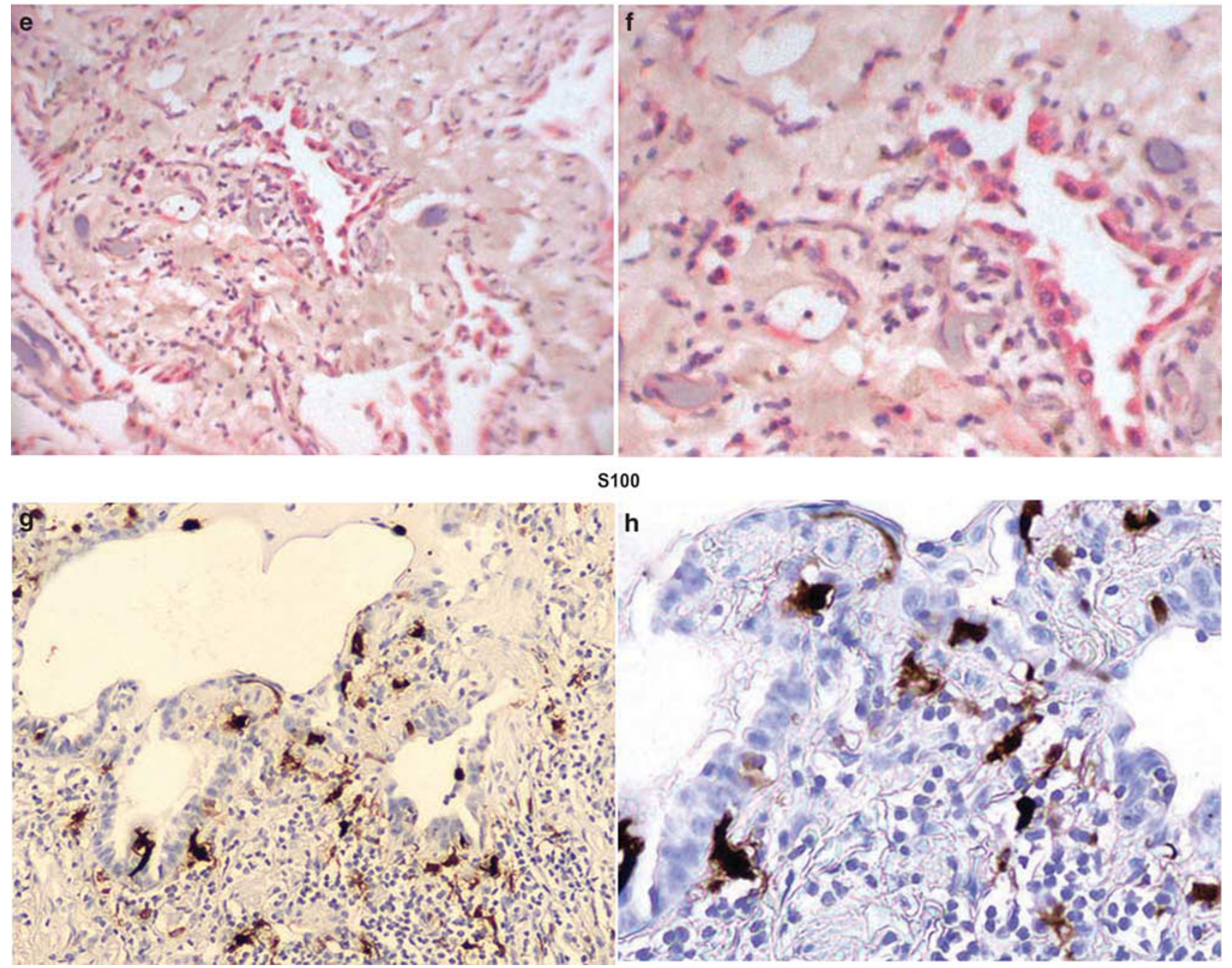

Figure 5 Continued.

(Table 1; Figure 6a-f), and CCR6 (Figure 6a-d) or IL-17 (Figure 6e and f). The cells that co-expressed CCR6 and cytokeratins were the regenerating epithelial cells (Figure 6a and d). $\mathrm{IL}_{-} 17^{+} /$cytokeratin $\mathrm{AE} 1 / 3^{+}$cells can be seen $(36 \%$ of epithelial cells were stained; Figure $6 \mathrm{f}$ ), and $\mathrm{IL}-17^{+} /$cytokeratin $\mathrm{AE} 1 / 3^{-}$cells are visible in the surrounding stroma (Figure 6e and f).

\section{IL-17-Producing Macrophages and T-Cells in Idiopathic Pulmonary Fibrosis}

To determine the identity of the interstitial/stromal cells and to verify the identity of the alveolar macrophages expressing IL-17, idiopathic pulmonary fibrosis lung tissues were probed with antibody to IL-17, CD3 and CD68 (Figure 7). Some of the $\mathrm{IL}^{-17^{+}}$interstitial cells were $\mathrm{CD} 3^{+}$, indicating that Th-17 lymphocytes were present in the stroma (Figure $7 \mathrm{a}$ and $\mathrm{b}$ ). Cells positive for IL-17 and CD68 were macrophages (Figure $7 \mathrm{c}$ and d).

\section{IL-17-Producing Cells Expressing RORs in Idiopathic Pulmonary Fibrosis}

Th-17 lymphocytes can be identified by the presence of the nuclear orphan receptor ROR- $\gamma,{ }^{34}$ which controls IL-17 production and CCR6 expression. ${ }^{35}$ Similar to ROR- $\gamma,{ }^{36}$ ROR- $\alpha$ is necessary for lymphocyte development ${ }^{37}$ and promotes Th-17 differentiation. ${ }^{38}$ A third member of the ROR family is ROR- $\beta$. Antibodies to these nuclear orphan receptors were used to probe either control or idiopathic pulmonary fibrosis lung tissue. Expression of ROR- $\beta$ and $-\gamma$ was apparent in all stages of idiopathic pulmonary fibrosis (Figure 8). The numbers of cells positive for ROR $-\alpha,-\beta$, and $-\gamma$ were significantly higher in the epithelial-dominant stage of idiopathic pulmonary fibrosis than in control lung tissue $(P=0.0216$, $P=0.0018$, and $P=0.0009$, respectively). Similar to IL-17 and CCR6, the positive staining for all three RORs appeared to localize in regenerating epithelial cells. To clarify the identity of these cells, colocalization studies were performed (Figure 9). 


\section{CCR6 + cytokeratin AE1/3}

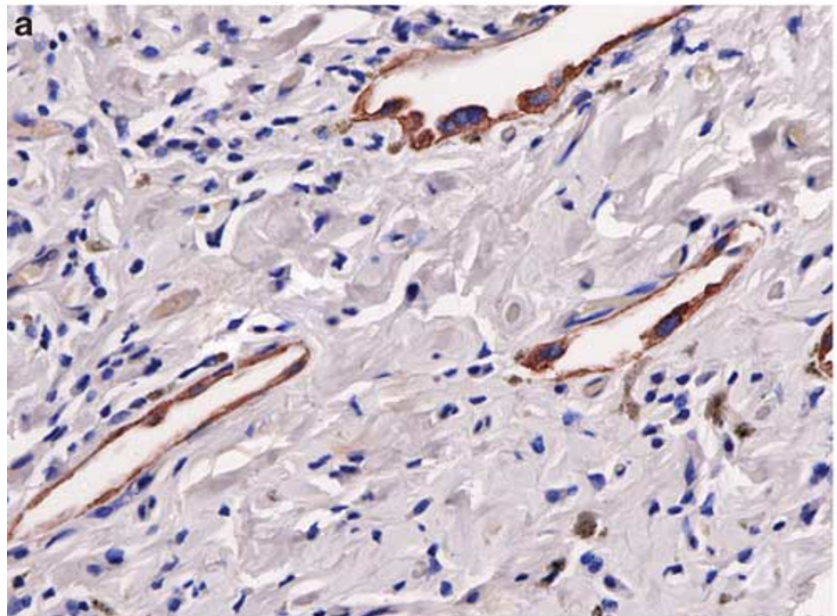

\section{CCR6}

C

\section{IL-17}

e cytokeratin AE1/3

b

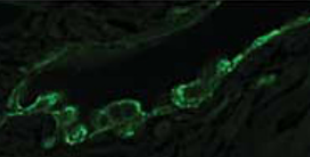

\section{CCR6 + cytokeratin AE1/3}

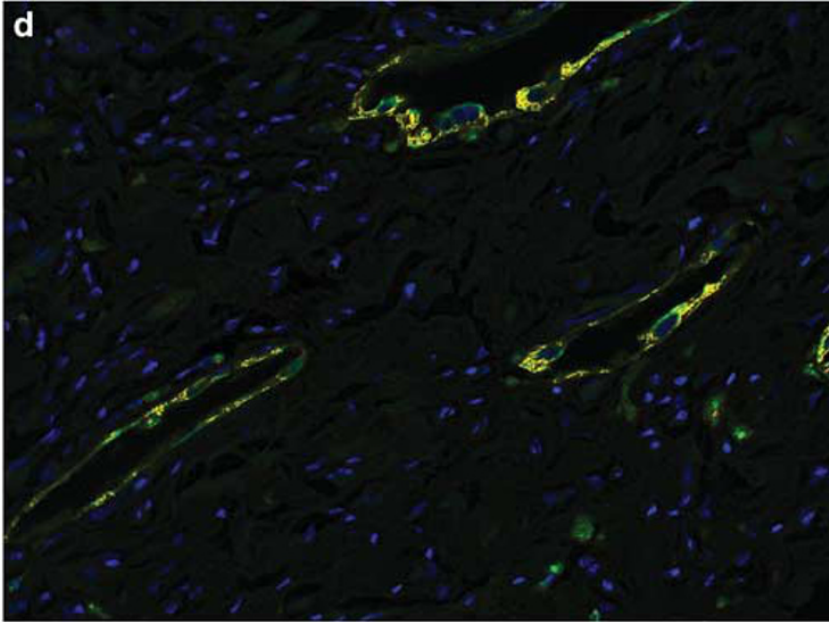

IL-17 + cytokeratin AE1/3

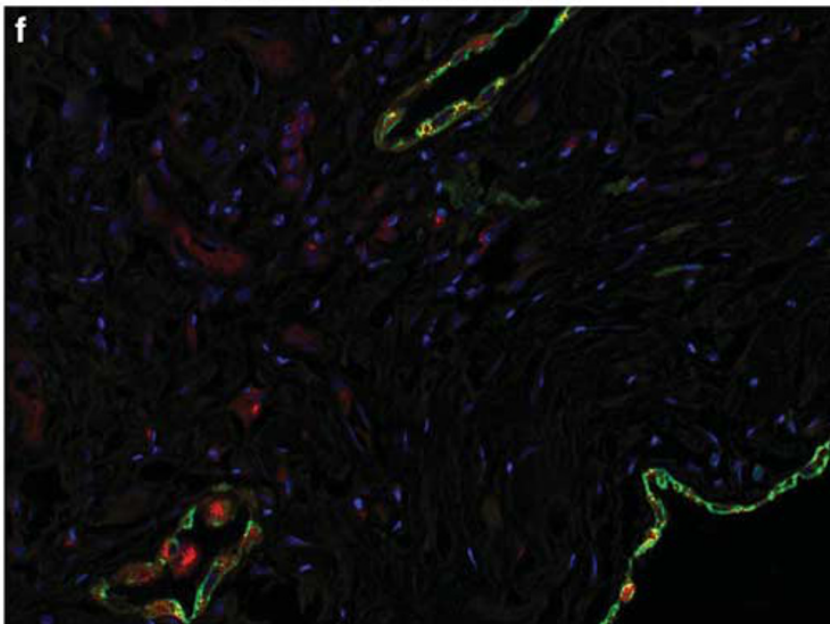

Figure 6 Co-expression analyses of epithelial cytokeratins, CCR6 and IL-17, in the idiopathic pulmonary fibrosis-epithelial-dominant areas. (a-d) The images are photos of the same slide, as are panels $\mathbf{e}$ and $\mathbf{f}$. (a) The color-based image where the bound cytokeratin AE1/3 $\mathrm{Ab}$ appears brown (diaminobenzidine), CCR6 is red (Fast Red), and the counterstain (visible on nuclei) is blue (hematoxylin). (b) The Nuance system converts diaminobenzidine to fluorescent green showing the cytokeratins. (c, e) The CCR6 and IL-17 (Fast Red) are converted to fluorescent red, $(\mathbf{d}, \mathbf{f})$ fluorescent yellow marks cells with both targets. (d) The CCR6 ${ }^{+}$cells co-express cytokeratins. (f) Co-expression analyses with IL-17 show that the epithelial $\mathrm{IL}-17^{+}$cells are cytokeratin AE1/3 Ab ${ }^{+}$, but many IL-17 ${ }^{+} /$cytokeratin $\mathrm{AE} 1 / 3^{-}$cells are fluorescent red in the stroma. 
$\mathrm{IL}-17+\mathrm{CD} 3$

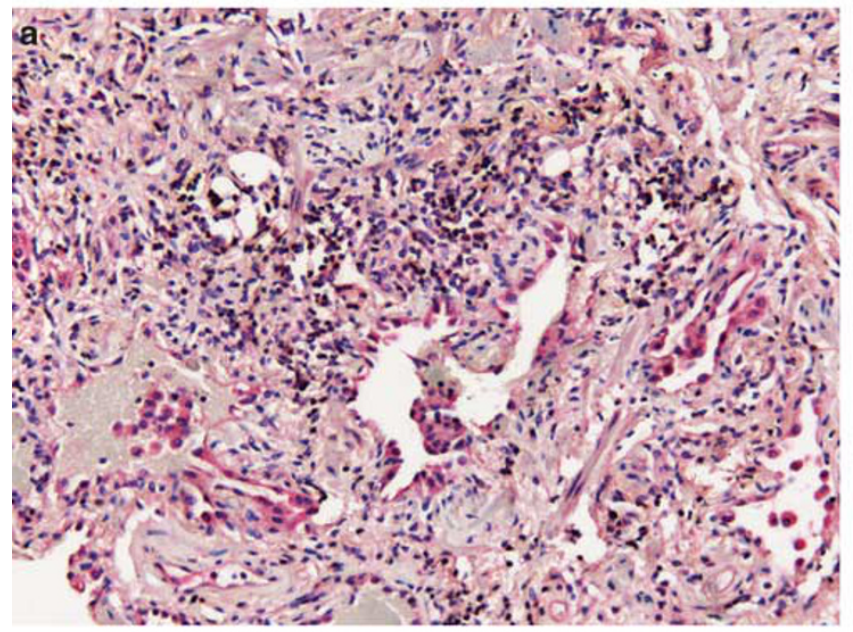

$\mathrm{IL}-17+\mathrm{CD} 68$

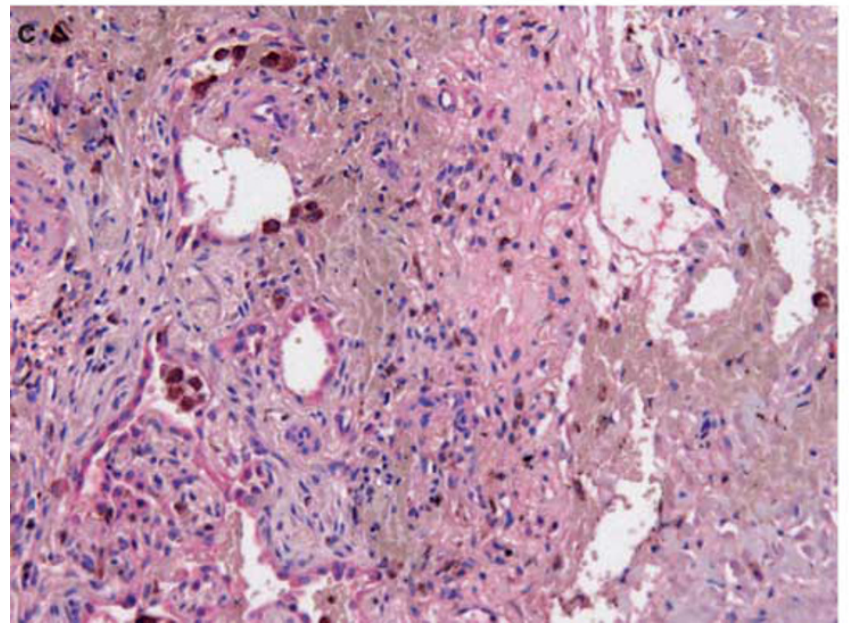

IL-17 + CD3

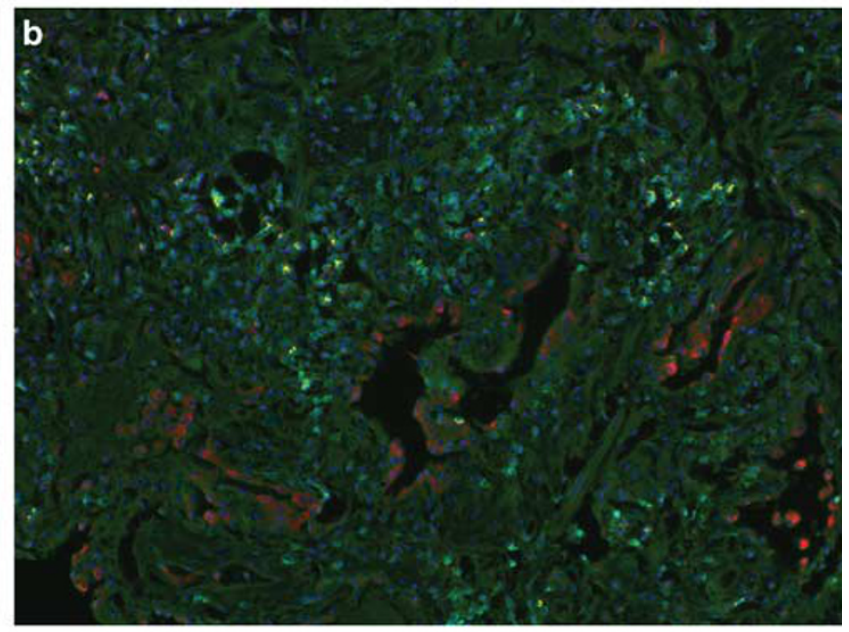

$\mathrm{IL}-17+\mathrm{CD} 68$

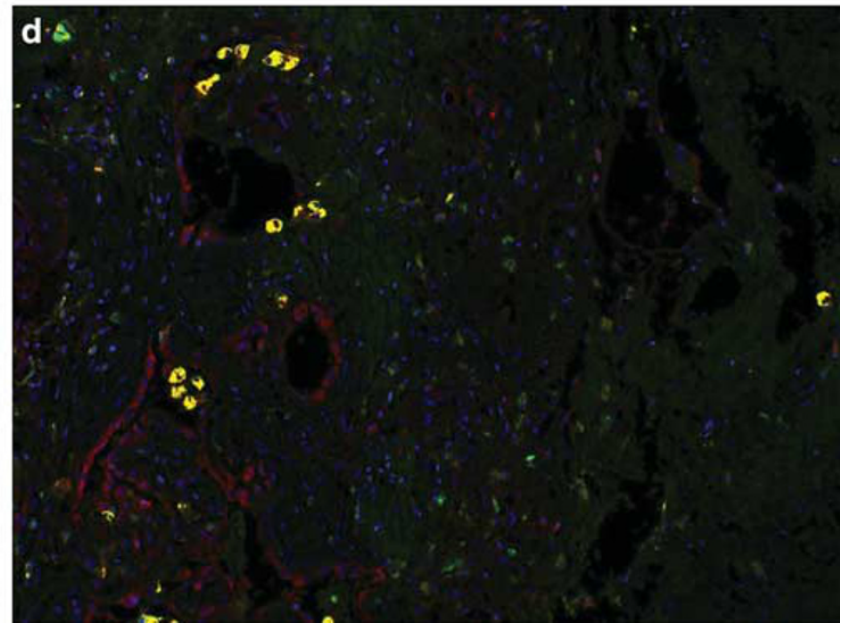

Figure 7 Co-expression analyses of IL-17 with CD3 and CD68 in the idiopathic pulmonary fibrosis-epithelial-dominant stage. (a) The color-based image where the CD3 is stained brown (diaminobenzidine), IL-17 is red (Fast Red), and the counterstain is blue (hematoxylin). (b) The same image made fluorescent by the Nuance system. Some double-positive (yellow) stained cells are present in the interstitium (Th-17s), and some of the $\mathrm{CD}^{+} \mathrm{T}$ cells are green, both have the morphology of lymphocytes. Fast-Red-labeled cells (IL-17 ${ }^{+}$, non-T cells) are also apparent. (c) The regular color-based image with CD68 ${ }^{+}$stained brown (diaminobenzidine), and the IL-17 is again stained with Fast Red. (d) The same image made fluorescent with double-positive macrophages (yellow), some green macrophages $\left(\mathrm{CD}^{+} 8^{+}\right)$in the interstitium, and red fluorescent $\left(\mathrm{IL}^{-17^{+}}\right)$regenerating epithelial cells.

Most of the ROR- $\alpha^{+}$cells co-expressed epithelial cytokeratins (detected by cytokeratin AE1/3 Ab), suggesting they were lung epithelial cells (Figure 9j). Many cells expressing ROR- $\beta$ (Figure 9k), ROR- $\gamma$ (Figure 9l), and IL-17 (Figure 6f) also co-expressed these cytokeratins and were identified as regenerating epithelial cells. These results are surprising, because Th-17s, macrophages, ${ }^{39,40}$ and histiocytes ${ }^{41}$ are the reported sources of the cytokine IL-17. However, as evident in Figure 6e and f, stromal cells also expressed IL-17. RORs were evident on endothelial cells, defined as flattened cells lining small blood vessels (data not shown), scattered interstitial cells and inflammatory cells. Control lung epithelium was nearly devoid of cells positive for ROR- $\alpha,-\beta$, and $-\gamma$ (Figure 9m, n, and o).

\section{Characterization of the Stromal-Dominant Regions of Idiopathic Pulmonary Fibrosis Lung}

The immunophenotypical profiles of the different antigens in the stromal-dominant histological areas of idiopathic pulmonary fibrosis lung tissues were also examined. These data are presented in Figures 1, 2, and 8 . There was a marked decrease in the number of cells expressing CD3, CD8, CD20, CD45, and CD68 in the stromal-dominant stage of idiopathic pulmonary fibrosis compared with the epithelial-dominant stage. The trend for significantly fewer CD45RO ${ }^{+}$cells across the histological spectrum of idiopathic pulmonary fibrosis was demonstrated for the stromal dominant versus the epithelial-dominant stage of idiopathic pulmonary 


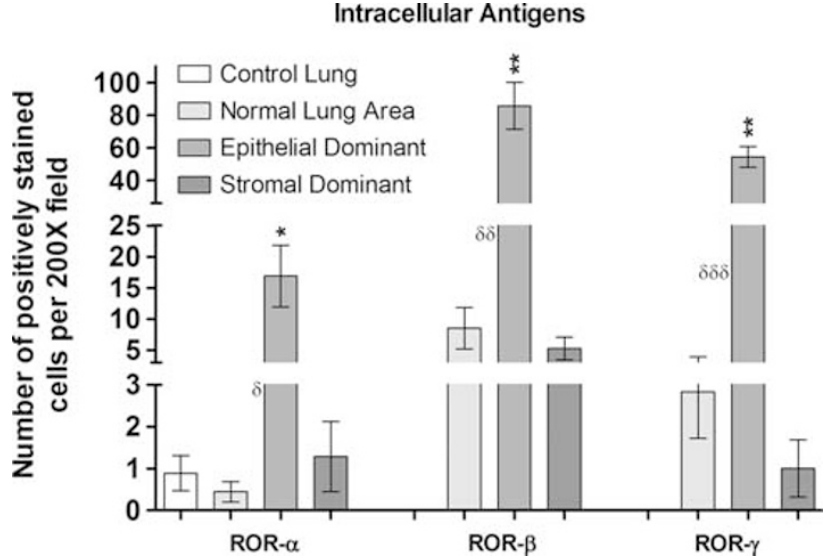

Figure 8 Intracellular retinoid-like ROR-positive cells. The mean \pm s.e.m. of the numbers of interstitial cells stained positive for the ROR antigens on slides with areas of lung tissue representing the signature idiopathic pulmonary fibrosis histological regions and control lung tissue. Asterisks indicate the $P$-values for comparison of the idiopathic pulmonary fibrosis tissues with the control lung tissue $\left({ }^{*} P<0.05 ;{ }^{*} P<0.005\right)$. Deltas indicate the $P$-values for comparison of the differences involving the data bars that they appear between $\left({ }^{\delta} P<0.05 ;{ }^{\delta \delta} P<0.005\right.$; and $\left.{ }^{\delta \delta \delta} P<0.0005\right)$.

fibrosis $(P=0.002)$. There were far fewer cells expressing TNF- $\alpha$, CD80, IL-17, CCR6, S100, ROR- $\alpha$, ROR- $\beta$, and ROR- $\gamma$ in the stromal-dominant stage of idiopathic pulmonary fibrosis versus the epithelial-dominant stage. Similarly, there was minimal to no expression of Foxp3, CD34, and CD56 (data not shown). The overall decrease in the numbers of immune cells in the end stage of idiopathic pulmonary fibrosis may be attributed to the replacement of parenchymal tissue with fibrotic scar tissue.

\section{Discussion}

The major new finding of this study, confirmed by co-expression analyses, was that the regenerating lung epithelial cells in idiopathic pulmonary fibrosis express proteins previously thought to be expressed only by immune cells (Figure 9). A role for the highly inflammatory IL-17 has been implicated in human asthma, ${ }^{39,42} \mathrm{COPD},{ }^{43}$ experimental hypersensitivity pneumonitis, ${ }^{44}$ murine models of pulmonary fibrosis, ${ }^{11}$ and all autoimmune diseases that have been tested for its presence. ${ }^{45}$ Our results show the cell-specific expression of IL-17 in the lungs of idiopathic pulmonary fibrosis patients, unexpectedly localized to regenerating epithelial cells, as well as alveolar macrophages and T-cells. Molecules expressed by Th-17 cells, including CCR6, ${ }^{33,35}$ ROR- $\gamma^{35}$ and ROR- $\alpha,{ }^{38}$ were co-expressed with IL-17 in regenerating epithelial cells (Figures 6 and 9). Figure $6 \mathrm{~d}$ and $\mathrm{f}$ (respectively) show the co-expression of CCR6 and IL-17 with epithelial cytokeratins using the cytokeratin AE1/3 Ab, and Figure 9 shows the co-expression of ROR- $\alpha,-\beta$, and $-\gamma$ with epithelial cytokeratins. Figure 7 shows co-expression of IL-17 with CD3 and CD68, verifying the cellular identity as Th-17 lymphocytes and macrophages, respectively. The novel, unexpected finding of IL-17, CCR6, and all the three RORs in regenerating epithelial cells (but not histologically normal epithelium) in idiopathic pulmonary fibrosis warrants further exploration.

CCR6 was initially described as a chemokine receptor on memory $\mathrm{T}$ cells, ${ }^{32}$ in particular on T-regs, ${ }^{46}$ which was specific for chemokine ligand 20 (CCL20). The expression of CCR6 on Th-17s and T-regs requires the expression of the nuclear receptors ROR- $\alpha$ and $-\gamma$, and regulates their migration into inflammatory tissue. ${ }^{47}$ We detected Th-17 lymphocytes in idiopathic pulmonary fibrosis lung stromal tissue (Figure $7 \mathrm{a}$ and $\mathrm{b}$ ), but few Foxp ${ }^{+}$ T-regs were found outside of inflammatory infiltrates (data not shown and Figure 4). This is consistent with an impaired regulatory T-cell response in idiopathic pulmonary fibrosis. ${ }^{48}$

The constant presence of bacteria promotes production of CCL20 in the intestines, and the intestinal epithelial cells constitutively express CCR6 in the colon and in culture. ${ }^{49}$ Both ligands for CCR6, CCL20, and human $\beta$-defensin-2 function in the activation of colonic epithelium for cellular migration and barrier repair via CCR6-regulated actin cytoskeleton pathways. ${ }^{50}$ The results of our colocalization experiments implicate a similar process taking place in the idiopathic pulmonary fibrosis lung epithelium, to repair the idiopathic damage in the alveoli.

The expression of the RORs by regenerating epithelium is intriguing, given that these are nuclear receptors affecting development of the immune and nervous systems, as demonstrated with ROR- $\gamma,{ }^{36}$ ROR- $\alpha,{ }^{37,51}$ and ROR- $\beta^{52}$ knockout mice. ROR- $\beta$ has been detected in the nervous system, leaving its function in idiopathic pulmonary fibrosis lung open for speculation. The RORs were initially named orphan receptors because their actual ligands were unknown. One ligand identified for ROR- $\beta$ is alltrans retinoic acid. ${ }^{53}$ Rats treated with all-trans retinoic acid have pulmonary consequences in their

\footnotetext{
Figure 9 Co-expression analyses of RORs and cytokeratins in the idiopathic pulmonary fibrosis-epithelial-dominant Areas. (a-c) The regular color-based images where the cytokeratin AE1/3 Ab is brown (diaminobenzidine); ROR- $\alpha,-\beta$, and $-\gamma$ are Fast Red labeled; and the counterstain is blue (hematoxylin). (d-l) The same images (arranged vertically) are fluorescence converted by the Nuance system. Most of the ROR-expressing cells are stained positive with the cytokeratin AE1/3 Ab. Control lung tissues were double stained with the same antibodies and color reagents, the co-expression is shown and labeled in panels $\mathbf{m}, \mathbf{n}$, and $\mathbf{o}$. Green fluorescence of the cytokeratin AE1/3 $\mathrm{Ab}$ can be seen, but co-expression with the RORs is absent.
} 


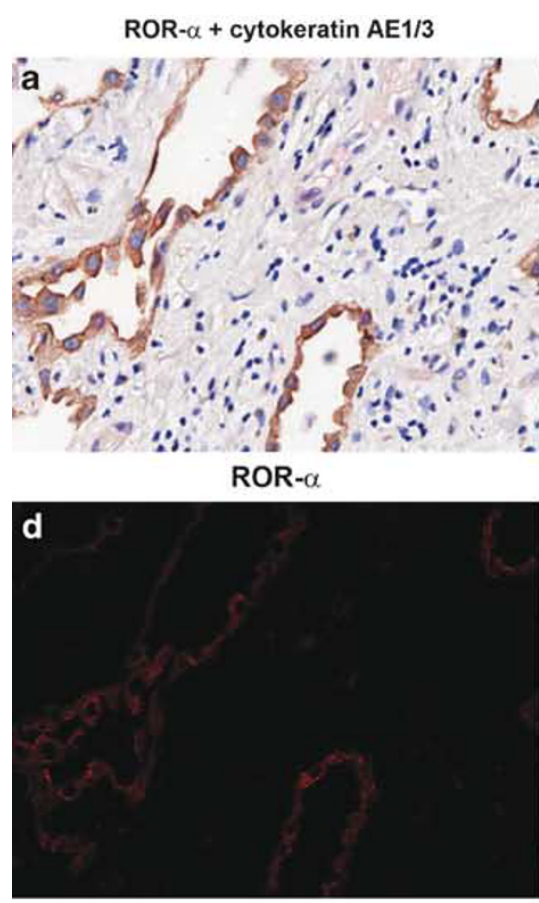

cytokeratin $\mathrm{AE} 1 / 3$

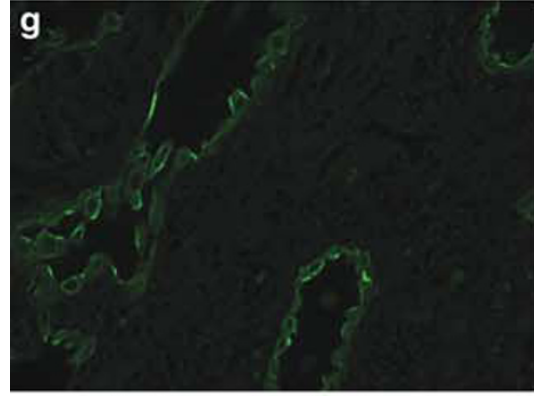

ROR- $\alpha$ + cytokeratin AE1/3

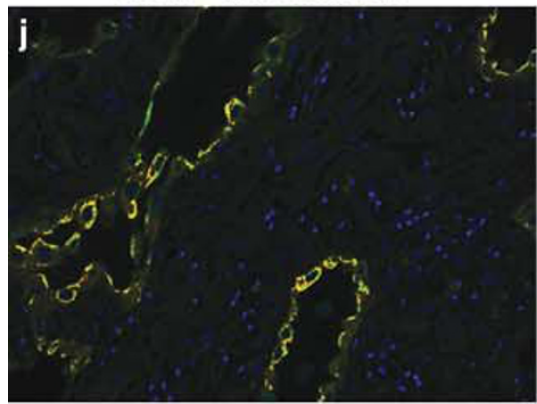

ROR- $\alpha+$ cytokeratin AE1/3

\section{m}

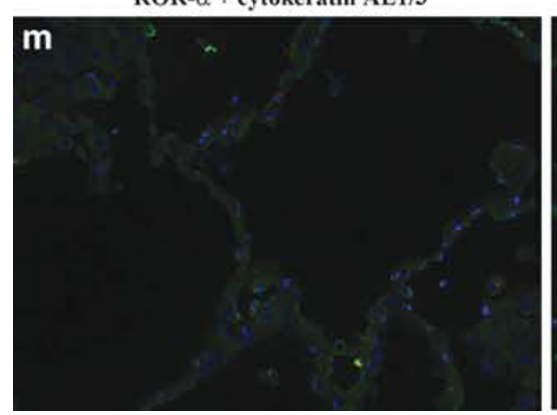

ROR- $\beta$ + cytokeratin $A E 1 / 3$

ROR- $\gamma$ + cytokeratin AE1/3

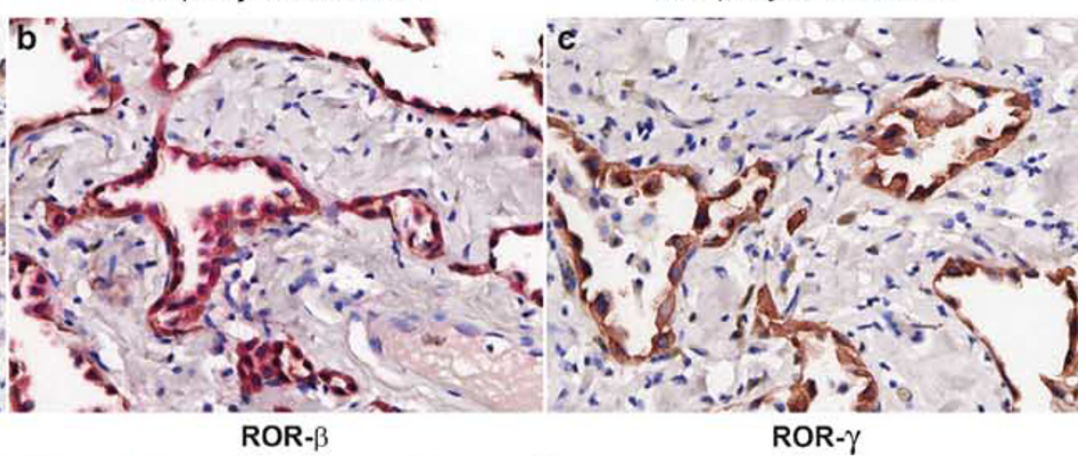

e

cytokeratin $\mathrm{AE} 1 / 3$

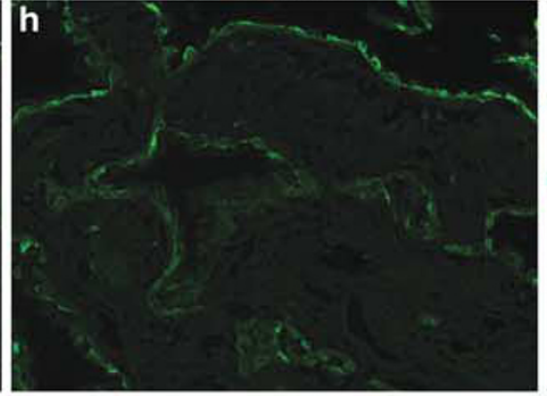

ROR- $\beta$ + cytokeratin $A E 1 / 3$

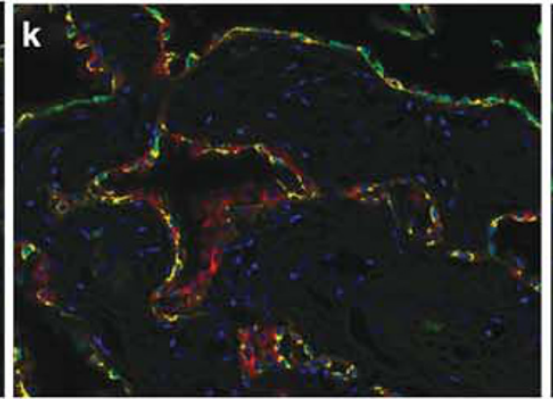

ROR- $\beta$ + cytokeratin AE1/3 f

cytokeratin $\mathrm{AE} 1 / 3$

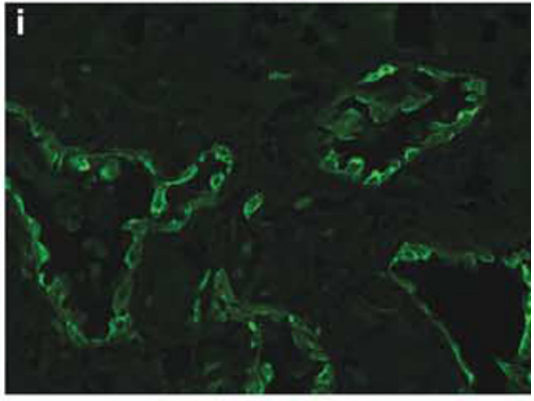

ROR- $\gamma$ + cytokeratin AE1/3

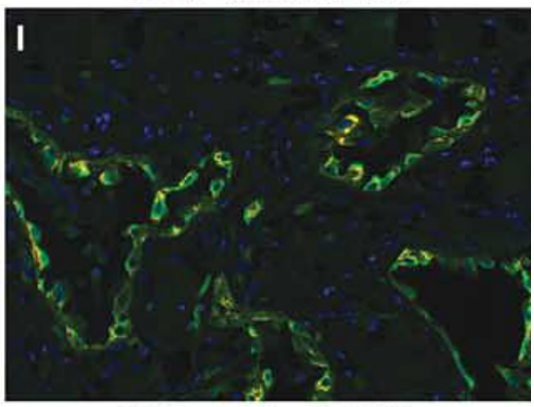

ROR- + cytokeratin AE1/3 n
○

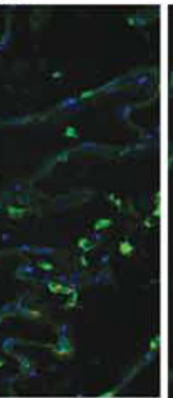


alveoli, such as postnatally developing more alveolar tissue and preventing dexamethasone-induced decreases in alveolar units. ${ }^{54}$ These interactions suggest a potential physiological role for the RORs in idiopathic pulmonary fibrosis lung epithelium regeneration. Transformed hematopoietic stem cells express receptors for vitamin A metabolites. ${ }^{55}$ The expression of ROR- $\beta$ on the regenerating epithelium deserves further investigation.

ROR- $\alpha$ is located on chromosome 15q22.2, in a known common fragile site (FRA15A), where gene rearrangements tend to occur, resulting in epithelial cancers of the breast, prostate, and ovaries. Its transcription is downregulated in cancer, whereas cellular stress, oxygen radicals, and toxins upregulate its expression. Upregulation of ROR- $\alpha$ slows cellular growth. ${ }^{56}$ Hypoxia also induces activation of ROR $-\alpha .{ }^{57}$ It is possible that lung tissue injury and resultant hypoxia in idiopathic pulmonary fibrosis trigger the expression of this gene in the regenerating epithelium.

Because IL-17 was detected in epithelial cells, we looked for ROR- $\gamma$ to localize to the same cells. Colocalization of ROR- $\gamma$ and $-\alpha$ in the regenerating epithelium (Figure 9) provides evidence that these cells were producing IL-17, rather than binding it via receptors on their surface from other sources. ${ }^{58}$ These nuclear factors control the development of IL-17-producing Th-17 cells. $^{34,38}$ The results we present call into question the source of the regenerating epithelia. The wide range of molecules expressed suggests that these IL-17-producing cells may be derived from hematopoietic progenitor cells. Murine studies of lung injury and fibrosis have demonstrated the ability of bone marrowderived cells to populate the alveoli and become type 1 pneumocytes. ${ }^{12,13}$ The expression of the hematopoietic progenitor cell marker Thy- $1^{29}$ by regenerating epithelial cells in idiopathic pulmonary fibrosis ${ }^{59}$ indicates the potential for hematopoietic cells to enter the damaged regions of lung parenchyma to attempt to heal the injury. Future studies will be required to identify the origin of the regenerating epithelium in idiopathic pulmonary fibrosis.

Early changes in the lungs of idiopathic pulmonary fibrosis patients provide valuable information for discovery of the etiology and the treatment of idiopathic pulmonary fibrosis. Compared with controls, the significant inflammatory changes in histologically normal lung areas in idiopathic pulmonary fibrosis biopsy samples were macrophage recruitment into the interstitium and heightened cellular expression of the antigen-presenting molecule CD80 (Figures 1 and 2). The recruitment of these innate immune system cells suggests the presence of a chemotactic mediator, such as a stress signal, emanating from the normal-appearing parenchyma. ${ }^{60,61}$ Heightened alveolar macrophage proliferation has also been reported to characterize and distinguish usual interstitial pneumonia from other interstitial lung diseases. ${ }^{62}$ The relative timing of these phenomena would be interesting to determine.

Some of our results confirmed the location of immune cells previously described for idiopathic pulmonary fibrosis lung tissue. We found TNF- $\alpha$ expression in macrophages and regenerating epithelial cells (Figure 5a and b), similar to previous reports. ${ }^{63}$ Other inflammation-associated molecules detected were S100 proteins (Figure $5 \mathrm{~g}$ and h), a family of intracellular and secreted calcium-binding proteins with regulatory activity. ${ }^{64}$ These are found in and produced by Langerhans dendritic cells, activated monocytes, macrophages, neutrophils, ${ }^{65}$ and fibrocytes. ${ }^{66}$ They function as Toll-like receptor agonists and chemoattractants; ${ }^{30}$ and are functionally modified by oxidation. ${ }^{31}$ IL-17 enhances expression of $\mathrm{S} 100$ proteins in murine and human skin inflammation. ${ }^{33,67}$ Our results clearly demonstrate inflammation in idiopathic pulmonary fibrosis and are consistent with previous reports of a role for adaptive autoimmunity in idiopathic pulmonary fibrosis. ${ }^{68}$ Once the epithelial-dominant stage of idiopathic pulmonary fibrosis deteriorates to the stromal-dominant stage, there is an apparent decrease in the numbers of cells expressing each of the immunomodulators studied. This underscores the realization that the end-stage of idiopathic pulmonary fibrosis is likely not reversible and that therapy needs to be directed to early disease events.

In summary, we detected and localized the inflammatory and autoimmune cytokine IL- $17^{69}$ in idiopathic pulmonary fibrosis lung. This could be an indication that autoimmune reactivity is present in the disease as suggested by others, ${ }^{7,8,68}$ or this could be another disease in which IL-17 has a role. ${ }^{33}$ Given the finding of IL-17-producing cells by Wilson et $a 1^{11}$ in a tracheal-injury murine model of pulmonary fibrosis, it is likely that this cytokine is not unique to idiopathic pulmonary fibrosis among the fibrotic lung diseases. This is the first report of colocalization of IL-17 with the orphan nuclear receptors ROR- $\alpha,-\beta$, and $-\gamma$, and the chemokine receptor CCR6 in cells that are acting as regenerating epithelia in idiopathic pulmonary fibrosis. These results raise many important questions regarding the source of regenerating epithelial cells in the lung, and the potential pathological role that they have in their attempt to heal alveolar injury.

\section{Acknowledgements}

We thank Kathleen Sergott for assistance with the immunohistochemical part of the study; Margaret Nuovo (MD) for her assistance with the photography and the creation of the Figures; and Dr Moises Selman for providing some of the idiopathic pulmonary fibrosis lung tissues analyzed in this study. This project was supported by award numbers 
R21HL093675 (VAF) and R01HL067176 (CBM) from the National Heart, Lung, and Blood Institute of the National Institutes of Health. The content is solely the responsibility of the authors and does not necessarily represent the official views of the National Heart, Lung, and Blood Institute or the National Institutes of Health.

\section{Disclosure/conflict of interest}

The authors declare no conflict of interest.

\section{References}

1 Olsen AL, Swigris JJ, Lezotte DC, et al. Mortality from pulmonary fibrosis increased in the United States from 1992 to 2003. Am J Respir Crit Care Med 2007;176:277-284.

2 Raghu G, Collard HR, Egan JJ, et al. American Thoracic Society Documents. An official ATS/ERS/ JRS/ALAT statement: idiopathic pulmonary fibrosis: evidence-based guidelines for diagnosis and management. Am J Respir Crit Care Med 2011;183:788-824.

3 Katzenstein A-LA, Mukhopadhyay S, Myers JL. Diagnosis of usual interstitial pneumonia and distinction from other fibrosing interstitial lung diseases. Hum Pathol 2008;39:1562-1581.

4 Chapman HA. Disorders of lung matrix remodeling. J Clin Invest 2004;113:148-157.

5 Selman M, Pardo A, Kaminski N. Idiopathic pulmonary fibrosis: aberrant recapitulation of developmental programs? PLoS Med 2008;5:e62.

6 Bringardner BD, Baran CP, Eubank TD, et al. The role of inflammation in the pathogenesis of idiopathic pulmonary fibrosis. Antioxid Redox Signal 2008;10: 287-301.

7 Magro CM, Allen J, Pope-Harman A, et al. The role of microvascular injury in the evolution of idiopathic pulmonary fibrosis. Anat Pathol 2003;119: 556-567.

8 Magro CM, Waldman WJ, Knight DA, et al. Idiopathic pulmonary fibrosis related to endothelial injury and antiendothelial cell antibodies. Hum Immunol 2006; 67:284-297.

9 Tang Y-W, Johnson JE, Browning PJ, et al. Herpesvirus DNA is consistently detected in lungs of patients with idiopathic pulmonary fibrosis. J Clin Microbiol 2003;41:2633-2640.

10 Bhatt N, Baran CP, Allen J, et al. Promising pharmacologic innovations in treating pulmonary fibrosis. Curr Opin Pharmacol 2006;6:284-292.

11 Wilson MS, Madala SK, Ramalingam TR, et al. Bleomycin and IL-1B-mediated pulmonary fibrosis is IL-17A dependent. J Exp Med 2010;207:1-18.

12 Kotton DN, Ma BY, Cardoso WV, et al. Bone marrowderived cells as progenitors of lung alveolar epithelium. 2001;128:5181-5188.

13 Hashimoto N, Jin H, Liu T, et al. Bone marrow-derived progenitor cells in pulmonary fibrosis. J Clin Invest 2004;113:243-252.

14 Mehrad B, Burdick MD, Strieter RM. Fibrocyte CXCR4 regulation as a therapeutic target in pulmonary fibrosis. Int J Biochem Cell Biol 2009;41:1708-1718.

15 Moeller A, Gilpin SE, Ask K, et al. Circulating fibrocytes are an indicator of poor prognosis in idiopathic pulmonary fibrosis. Am J Respir Crit Care Med 2009;179:588-594.

16 Garcia-de-Alba C, Becerril C, Ruiz V, et al. Expression of matrix metalloproteases by fibrocytes: possible role in migration and homing. Am J Respir Crit Care Med 2010;182:1144-1152.

17 Andersson-Sjoland A, Garcia-de-Alba C, Nihlberg K, et al. Fibrocytes are a potential source of lung fibroblasts in idiopathic pulmonary fibrosis. Int J Biochem Cell Biol 2008;40:2129-2140.

18 Cool CD, Groshong SD, Rai PR, et al. Fibroblastic foci are not discrete sites of lung injury or repair. Am J Respir Crit Care Med 2006;174:654-658.

19 Yamada M, Kuwano K, Maeyama T, et al. Dualimmunohistochemistry provides little evidence for epithelial-mesenchymal transition in pulmonary fibrosis. Histochem Cell Biol 2008;129:453-462.

20 Kalluri R, Neilson EG. Epithelial-mesenchymal transition and its implications for fibrosis. J Clin Invest 2003; 112:1776-1784.

21 Harrington LE, Hatton RD, Mangan PR, et al. Interleukin 17-producing CD4+ effector T cells develop via a lineage distinct from the $\mathrm{T}$ helper type 1 and 2 lineages. Nat Immunol 2005;6:1123-1132.

22 Park H, Li Z, Yang XO, et al. A distinct lineage of CD4 $\mathrm{T}$ cells regulates tissue inflammation by producing interleukin 17. Nat Immunol 2005;6:1133-1141.

23 Weaver CT, Hatton RD, Mangan PR, et al. IL-17 family cytokines and the expanding diversity of effector T cell lineages. Annu Rev Immunol 2007;25:821-852.

24 Feuerer M, Hill JA, Mathis D, et al. Foxp3+ regulatory T cells: differentiation, specification, subphenotypes. Nat Immunol 2009;10:689-695.

25 Nuovo GJ. In situ detection of microRNAs in paraffin embedded, formalin fixed tissues and the co-localization of their putative targets. Methods 2010;52: 307-315.

26 Nuovo GJ, Elton TS, Nana-Sinkam P, et al. A methodology for the combined in situ analyses of the precursor and mature forms of microRNAs and correlation with their putative targets. Nat Protoc 2009;4:107-115.

27 Mansfield JR. Cellular context in epigenetics: quantitative multicolor imaging and automated percell analysis of miRNAs and their putative targets. Methods 2010;52:271-280.

28 Marchal-Somme J, Uzunhan Y, Marchand-Adam S, et al. Cutting Edge: nonproliferating mature immune cells form a novel type of organized lymphoid structure in idiopathic pulmonary fibrosis. J Immunol 2006;176:5735-5739.

29 Craig W, Kay R, Cutler RL, et al. Expression of Thy-1 on human hematopoietic progenitor cells. J Exp Med 1993;177:1331-1342.

30 Ehrchen JM, Sunderkotter C, Foell D, et al. The endogenous Toll-like receptor 4 agonist S100A8/ S100A9 (calprotectin) as innate amplifier of infection, autoimmunity, and cancer. J Leukoc Biol 2009;86: 557-566.

31 Lim SY, Raftery MJ, Goyette J, et al. Oxidative modifications of $\mathrm{S} 100$ proteins: functional regulation by redox. J Leukoc Biol 2009;86:577-587.

32 Liao F, Rabin RL, Smith CS, et al. CC-chemokine receptor 6 is expressed on diverse memory subsets of $\mathrm{T}$ cells and determines responsiveness to macrophage inflammatory protein 3a. J Immunol 1999;162: 186-194. 
33 Pene J, Chavalier S, Preisser L, et al. Chronically inflamed human tissues are infiltrated by highly differentiated Th17 lymphocytes. J Immunol 2008;180: 7423-7430.

34 Ivanov II, McKenzie BS, Zhou L, et al. The orphan nuclear receptor RORgammat, directs the differentiation program of proinflammatory IL-17 T helper cells. Cell 2006;126:1121-1133.

35 Manel N, Unutmaz D, Littman DR. The differentiation of human Th-17 cells requires transforming growth factor-B and induction of the nuclear receptor RORyt. Nat Immunol 2008;9:641-649.

36 Kurebayashi S, Ueda E, Sakaue M, et al. Retinoidrelated orphan receptor gamma (RORgamma) is essential for lymphoid organogenesis and controls apoptosis during thymopoiesis. Proc Natl Acad Sci 2000;97: 10132-10137.

37 Dzhagalov I, Giguere V, He Y-W. Lymphocyte development and function in the absence of retinoic acid-related orphan receptor a. J Immunol 2004;173: 2952-2959.

38 Yang XO, Pappu BP, Nurieva R, et al. T helper 17 lineage differentiation is programmed by orphan nuclear receptors RORalpha and ROR gamma. Immunity 2008;28:29-39.

39 Song C, Luo L, Lei Z, et al. IL-17-producing alveolar macrophages mediate allergic lung imflammation related to asthma. J Immunol 2008;181: 6117-6124.

40 Zhu X, Mulcahy LA, Mohammed RAA, et al. IL-17 expression by breast-cancer-associated macrophages: IL-17 promotes invasiveness of breast cancer cell lines. Breast Cancer Res 2008;10:R95.

41 Coury F, Annels N, Rivollier A, et al. Langerhans cell histiocytosis reveals a new IL-17A-dependent pathway of dendritic cell fusion. Nat Med 2008;14: 81-87.

42 Molet S, Hamid Q, Davoine F, et al. IL-17 is increased in asthmatic airways and induces human bronchial fibroblasts to produce cytokines. J Allergy Clin Immunol 2001;108:430-438.

43 Doe C, Bafadhel M, Siddiqui S, et al. Expression of the $\mathrm{T}$ helper 17-associated cytokines IL-17A and IL-17F in Asthma and COPD. Chest 2010;138:1140-1147.

44 Joshi AD, Fong DJ, Oak SR, et al. Interleukin-17mediated immunopathogenesis in experimental hypersensitivity pneumonitis. Am J Respir Crit Care Med 2009;179:705-716.

45 Bettelli E, Oukka M, Kuchroo VK. Th-17 cells in the circle of immunity and autoimmunity. Nat Immunol 2007;8:345-350.

46 Kleinewietfeld M, Puentes F, Borsellino G, et al. CCR6 expression defines regulatory effector/memory-like cells within the CD25+CD4+ T-cell subset. Blood 2005;105:2877-2886.

47 Yamazaki T, Yang XO, Chung Y, et al. CCR6 regulates the migration of inflammatory and regulatory T cells. J Immunol 2008;181:8391-8401.

48 Kotsianidis I, Nakou E, Bouchliou I, et al. Global impairment of CD4+ CD25+ FOXP3+ regulatory T cells in idiopathic pulmonary fibrosis. Am J Respir Crit Care Med 2009;179:1121-1130.

49 Yang CC, Ogawa H, Dwinell MB, et al. Chemokine receptor CCR6 transduces signals that activate p130 Cas and alter cAMP-stimulated ion transport in human intestinal epithelial cells. Am J Physiol Cell Physiol 2005;288:C321-C3C8.
50 Vongsa RA, Zimmerman NP, Dwinell MB. CCR6 regulation of the actin cytoskeleton orchestrates human beta defensin-2- and CCL20-mediated restitution of colonic epithelial cells. J Biol Chem 2009;284: 10034-10045.

51 Steinmayr M, Andre E, Conquet F, et al. Staggerer phenotype in retinoid-related orphan receptor a-deficient mice. Proc Natl Acad Sci 1998;95:3960-3965.

52 Andre E, Conquet F, Steinmayr M, et al. Disruption of retinoid-related orphan receptor b changes circadian behavior, causes retinal degeneration and leads to vacillans phenotype in mice. EMBO J 1998;17: 3867-3877.

53 Stehlin-Gaon C, Willmann D, Zeyer D, Sanglier S, Dorsselaer AV, Renaud J-P, et al. All-trans retinoic acid is a ligand for the orphan nuclear receptor RORb. Nat Struct Biol 2003;10:820-825.

54 Massaro GD, Massaro D. Postnatal treatment with retinoic acid increases the number of pulmonary alveoli in rats. Am J Physiol 1996;270:L305-LL10.

55 Degos L, Wang ZY. All trans retinoic acid in acute promyelocytic leukemia. Oncogene 2001;20: 7140-7145.

56 Zhu Y, McAvoy S, Kuhn R, et al. RORA, a large common fragile site gene, is involved in cellular stress response. Oncogene 2006;25:2901-2908.

57 Miki N, Ikuta M, Matsui T. Hypoxia-induced activation of the retinoic acid receptor-related orphan receptor a4 gene by an interaction between hypoxiainducible factor-1 and sp1. J Biol Chem 2004;279: 15025-15031.

58 Moseley TA, Haudenschild DR, Rose L, et al. Interleukin-17 family and IL-17 receptors. Cytokine Growth Factor Rev 2003;14:155-174.

59 Sanders YY, Pardo A, Selman M, et al. Thy-1 promoter hypermethylation: a novel epigenetic pathogenic mechanism in pulmonary fibrosis. Am J Respir Cell Mol Biol 2008;39:610-618.

60 Beilhack A, Rockson SG. Immune traffic: a functional overview. Lymphat Res Biol 2003;1:219-234.

61 Lotze MT, Tracey KJ. High-mobility group box 1 (HMGB1): nuclear weapon in the immune arsenal. Nat Rev Immunol 2005;5:331-342.

62 El-Zammar O, Rosenbaum P, Katzenstein A-LA. Proliferative activity in fibrosing lung diseases: a comparative study of Ki-67 immunoreactivity in diffuse alveolar damage, bronchiolitis obliterans-organizing pneumonia, and usual interstitial pneumonia. Hum Pathol 2009;40:1182-1188.

63 Piguet PF, Ribaux C, Karpuz V, et al. Expression and localization of tumor necrosis factor-a and its mRNA in idiopathic pulmonary fibrosis. Am J Pathol 1993;143:651-655.

64 Donato R. Intracellular and extracellular roles of S100 proteins. Microsc Res Tech 2003;60:540-551.

65 Nacken W, Roth J, Sorg C, et al. S100A9/S100A8: myeloid representatives of the $\mathrm{S} 100$ protein family as prominent players in innate immunity. Microsc Res Tech 2003;60:569-580.

66 Pilling D, Fan $\mathrm{T}$, Huang $\mathrm{D}$, et al. Identification of markers that distinguish monocyte-derived fibrocytes from monocytes, macrophages, and fibroblasts. PloS One 2009;4:e7475.

67 Liang SC, Tan X-Y, Luxenberg DP, et al. Interleukin (IL)-22 and IL-17 are coexpressed by Th17 cells and cooperatively enhance expression of antimicrobial peptides. J Exp Med 2006;203:2271-2279. 
68 Feghali-Bostwick CA, Tsai CG, Valentine VG, et al. Cellular and humoral autoreactivity in idiopathic pulmonary fibrosis. J Immunol 2007;179:2592-2599.

69 Miossec P, Korn T, Kuchroo VK. Interleukin-17 and type 17 helper T cells. N Engl J Med 2009;361:888-898.

70 Nascimento CR, Freire-de-Lima CG, Oliveira AdSd, et al. The short chain fatty acid sodium butyrate regulates the induction of CD1a in developing dendritic cells. Immunobiology 2011;216:275-284.

71 Reinherz EL, Kung PC, Goldstein G, et al. Discrete stages of human intrathymic differentiation: analysis of normal thymocytes and leukemic lymphoblasts of Tcell lineage. Proc Natl Acad Sci 1980;77:1588-1592.

72 Zajonc DM, Kronenberg M. CD1 mediated T cell recognition of glycolipids. Curr Opin Struct Biol 2007; 17:521-529.

73 Rocca GL, Anzalone R, Bucchieri F, et al. CD1a and antitumour immune response. Immunol Lett 2004;95: $1-4$.

74 Groh V, Gadner H, Radaszkiewicz T, et al. The phenotypic spectrum of histiocytosis X cells. J Invest Dermatol 1988;90:441-447.

75 Haskins K, Kubo R, White J, et al. The major histocompatibility complex-restricted antigen receptor on T cells. I. Isolation with a monoclonal antibody. J Exp Med 1983;157:1149-1169.

76 Zhu J, Yamane H, Paul WE. Differentiation of effector CD4 T cell populations. Annu Rev Immunol 2010; 28:445-489.

77 Shiku H, Kisielow P, Bean MA, et al. Expression of T-cell differentiation antigens on effector cells in cell-mediated cytotoxicity in vitro. J Exp Med 1975; 141:227-241.

78 Norment AM, Salter RD, Parham P, et al. Cell-cell adhesion mediated by CD8 and MHC class I molecules. Nature 1988;336:79-81.

79 Anolik J, Looney RJ, Bottaro A, et al. Down-regulation of CD20 on B cells upon CD40 activation. Eur J Immunol 2003;33:2398-2409.

80 Kuwana M, Okazaki Y, Kodama H, et al. Human circulating CD14+ monocytes as a source of progenitors that exhibit mesenchymal cell differentiation. J Leukoc Biol 2003;74:833-845.

81 Wood HB, May G, Healy L, et al. CD34 expression patterns during early mouse development are related to modes of blood vessel formation and reveal additional sites of hematopoiesis. Blood 1997;90: 2300-2311.

82 Curnow SJ, Fairclough M, Schmutz C, et al. Distinct types of fibrocyte can differentiate from mononuclear cells in the presence and absence of serum. PLoS One 2010;5:e9730.

83 Romagnani P, Annunziato F, Liotta F, et al. CD14+ CD34 $4^{\text {low }}$ cells with stem cell phenotypic and functional features are the major source of circulating endothelial progenitors. Circ Res 2005;97:314-322.
84 Kuwana M, Okazaki Y, Kodama H, et al. Endothelial differentiation potential of human monocyte-derived multipotential cells. Stem Cells 2006;24:2733-2743.

85 Trowbridge IS. CD45: An emerging role as a protein tyrosine phosphatase required for lymphocyte activation and development. Annu Rev Immunol 1994;12: 85-116.

86 Robertson MJ, Ritz J. Biology and Clinical relevance of human natural killer cells. Blood 1990;76:2421-2438.

87 Kunisch E, Fuhrmann R, Roth A, et al. Macrophage specificity of three anti-CD-68 monoclonal antibodies (KP1, EBM11, and PGM1) widely used for immunohistochemistry and flow cytometry. Ann Rheum Dis 2004;63:774-784.

88 Fujii S-I, Liu K, Smith C, et al. The linkage of innate to adaptive immunity via maturing dendritic cells in vivo requires CD40 ligation in addition to antigen presentation and CD80/86 costimulation. J Exp Med 2004;199: 1607-1618.

89 Linsley PS, Clark EA, Ledbetter JA. T-cell antigen CD28 mediates adhesion with $\mathrm{B}$ cells by interacting with activation antigen B7/BB-1. Proc Natl Acad Sci 1990;87:5031-5035.

90 Tsunawaki S, Nakamura S, Ohyama Y, et al. Possible function of salivary gland epithelial cells as nonprofessional antigen-presenting cells in the development of Sjogren's syndrome. J Rheumatol 2002;29:1884-1896.

91 Listrom MB, Dalton LW. Comparison of keratin monoclonal antibodies MAK-6, AE1:AE3, and CAM-5.2. Am J Clin Pathol 1987;88:297-301.

92 Moll R, Franke WW, Schiller DL, et al. The catalog of human cytokeratins: patterns of expression in normal epithelia, tumors and cultured cells. Cell 1982; 31:11-24

93 Tamas EF, Epstein JI. Detection of residual tumor cells in bladder biopsy specimens: pitfalls in the interpretation of cytokeratin stains. Am J Surg Pathol 2007;31:390-397.

94 Jetten AM. Recent advances in the mechanisms of action and physiological functions of the RetinoidRelated Orphan Receptors (RORs). Curr Drug Targets Inflamm Allergy 2004;3:395-412.

95 Jetten AM, Ueda E. Retinoid-related orphan receptors (RORs): roles in cell survival, differentiation and disease. Cell Death Differ 2002;9:1167-1171.

96 Sawa S, Cherrier M, Lochner M, et al. Lineage relationship analysis of RORgammat+ innate lymphoid cells. Science 2010;330:665-669.

97 Raichur S, Lau P, Staels B, et al. Retinoid-related orphan receptor gamma regulates several genes that control metabolism in skeletal muscle cells: links to modulation of reactive oxygen species production. J Mol Endocrinol 2007;39:29-44.

98 Locksley RM, Killeen N, Lenardo MJ. The TNF and TNF receptor superfamilies: integrating mammalian biology. Cell 2001;104:487-501. 